\title{
RADIOCARBON EVIDENCE OF THE MIDDLE TO UPPER PALAEOLITHIC TRANSITION IN SOUTHWESTERN EUROPE
}

\author{
LA TRANSICIÓN DEL PALEOLÍTICO MEDIO AL SUPERIOR EN EL SUROESTE \\ DE EUROPA EN BASE A LAS DATACIONES RADIOCARBÓNICAS
}

\author{
OLAF JÖRIS (*) \\ ESTEBAN ÁLVAREZ FERNÁNDEZ (**) \\ BERNHARD WENINGER $(* * *)$
}

\begin{abstract}
In the present paper we systematically evaluate the radiometric database underlying the Middle to Upper Palaeolithc transition in southwestern Europe.The different models which attempt to explain the demographical processes underlying this transition rely to a large degree on radiocarbon chronology. We observe that: 1) with increasing age, dates on bone samples show large offsets against those on charcoal, often underestimating these for several thousand years BP and; 2) there is no proof for a persistence of Middle Palaeolithic industries into the time of the earliest Aurignacian in SW Europe. These data contradict the "Ebro- Frontier" model that distinguishes Late Middle Palaeolithic industries in the SW of the Iberian Peninsula from early Aurignacian ones in the NE. On the contrary, our data 3) imply a model of interregional shifts of populations contracting during severe cold and arid phases and expanding under warmer, interstadial conditions, raising ideas on a regional in situ development of the SW European Aurignacian out of Latest Middle Palaeolithic industries made by Neanderthals some $40.0 \mathrm{kyr}$ cal BC.
\end{abstract}

\section{RESUMEN}

Se presenta un estudio sistemático sobre la información radiometrica disponible para la transición Paleolítico

(*) Forschungsbereich Altsteinzeit des Römisch-Germanischen Zentralmuseums, Schloß Monrepos. 56567 Neuwied. Germany. Correo electrónico: joeris.monrepos@rz-online.de

(**) Área de Prehistoria. Dpto. de Prehistoria, Historia Antigua y Arqueología. Fac. de Geografía e Historia. University of Salamanca. 37002 Salamanca. Spain. Correo electrónico: estebanalfer@hotmail.com

(***) ${ }^{14} \mathrm{C}$-Labor. Institut für Ur- und Frühgeschichte. University of Cologne. Weyertal 125. 50923 Cologne. Germany. Correo electrónico: b.weninger@uni-koeln.de

Recibido:1-VIII-03; aceptado: 25-VIII-03
Medio-Paleolítico Superior en el Suroeste de Europa. Los diferentes modelos para explicar el proceso demográfico que subyace en esta transición dependen en gran medida de la cronología radiocarbónica. Se observa que: 1) a mayor antiguedad las fechas sobre hueso muestran una mayor desvisación frente a las muestras sobre carbón, a menudo infravalorando estas varios miles de años BP y 2) que no hay pruebas de perduración de industrias de Paleolítico Medio durante las fases tempranas del Auriñaciense en el SW de Europa. Estos datos contradicen el modelo de "frontera del Ebro" que distingue industrias de Paleolítico Medio Tardío en el SW de la Península Ibérica de las industrias del Auriñaciense temprano en el NE. Por el contrario, 3) nuestros datos implican un modelo de cambios de población interregional que se contrae durante las fases aridas y de frío severo y que se expande durante las fases más calidas de los interestadios, surgiendo la idea de un desarrollo regional del Auriñaciense del SW europeo a partir de las industrias del Paleolítico Medio Tardío realizadas por los Neanderthales hace $40 \mathrm{kyr}$ cal BC.

Key words: Middle to Upper Palaeolithic transition. Colonization model. "Ebro-Frontier". Radiometric dates. Radiocarbon calibration. Palaeoclimate change. Population dynamics.

Palabras clave: Transición. Paleolítico Medio-Superior. Modelo de colonización. "Frontera del Ebro". Datación. Calibración. Cambio paleoclimático. Dinámica de población.

\section{INTRODUCTION}

The disappearance of Neanderthals is one of the most controversial questions in the study of homi- 


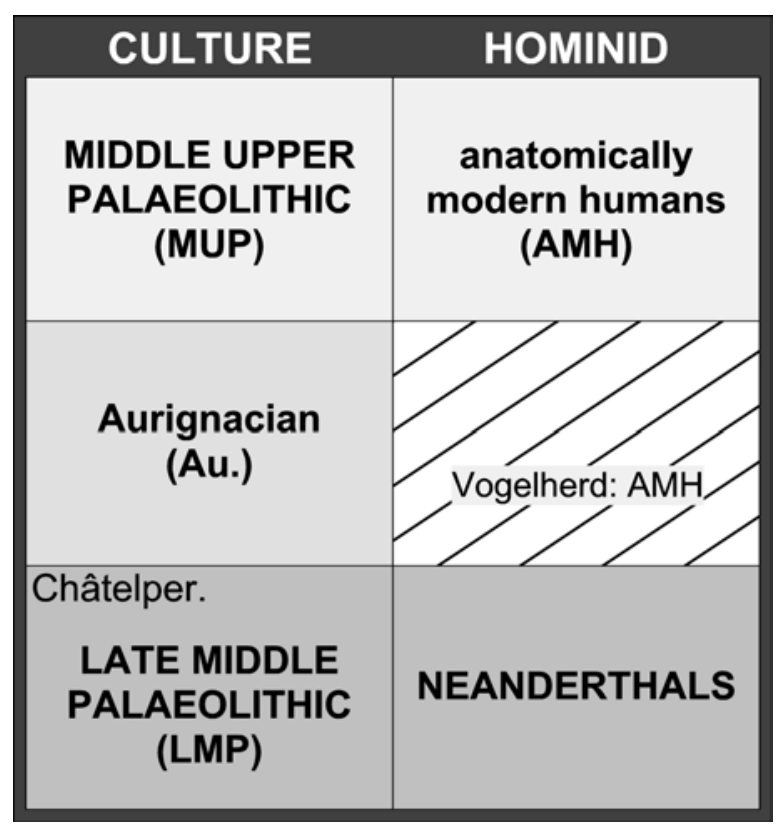

Fig. 1. Cultural sequence of Late Middle Palaeolithic to Middle Upper Palaeolithic technocomplexes in SW Europe compared with the hominid record.

nid evolution. Neanderthal fossil remains throughout Europe are exclusively known from pre-Aurignacian sites (Fig. 1), while early anatomically modern humans are exclusively tied to Upper Palaeolithic (UP) and younger technocomplexes (Churchill and Smith 2000; cf. Gambier 1997). Churchill and Smith evaluate the evidence for "the makers of the Early Aurignacian in Europe" and assert modern human presence in Europe "almost certainly" by ca. $32.0 \mathrm{kyr} \mathrm{BP}$, and - based on Rieks 1931 discovery of a modern human skull ("Stetten 1") from the base of the Aurignacian layer V of the southern German Vogelherd cave (Riek 1932; 1934) - they see a "strong possibility" that modern humans "were there by ca. $36 \mathrm{ka} \mathrm{BP}$ ". Although the new radiocarbon dates from the same stratum vary by several thousand years BP, they confirm the antiquity of the Aurignacian deposits at Vogelherd cave (Conard and Bolus 2003). But stratigraphic attribution of hominid fossils can rarely be established with certainty since skeletal remains may have been reworked in into older layers, a problem especially relevant for old excavations, which are often less well-documented. A good example is the recent dating of a perforated shell (Littorina sp.), found as a grave-good in a Cro-Magnon burial at the famous eponymous rock-shelter of the Gra- vettian period, which had formerly been attributed to an Aurignacian horizon at this site (Henry-Gambier 2002; cf. Djindjan et al. 1999). Being aware of such difficulties Cabrera Valdés et al. (2000: 91) state that the "only well-known human evidence for the time range 40-35 $\mathrm{ka}$ is either of Neanderthal or undiagnostic type [...], while the presence of modern human types is not certainly recognized in Europe until about $30 \mathrm{ka}$ ".

Nevertheless, the majority of models that today undertake efforts to explain the origin of anatomically modern humans is based on the "Out of Africa" hypothesis (Stringer and Andrews 1988; Stringer 2003), postulating colonization of Europe by early Homo sapiens with a simultaneous contraction of Neanderthal dispersal as expressed in the geographical spread of Middle Palaeolithic (MP) sites (Bocquet-Appel and Demars 2000). Recent studies in molecular genetics of fossil Neanderthal remains (Krings et al. 1997; 1999; Ovchinnikov et al. 2000) and new finds of early Homo sapiens in Ethiopia (White et al. 2003; cf. Clark et al. 2003) have provided substantial support for the "Out of Africa" hypothesis, whereby anatomically modern humans immigrated from Africa through the Near East into Europe replacing indigenous Neanderthal populations (Stringer 2003). This process - roughly placed between 40.0 and 30.0 kyr ago - is generally assumed to be unidirectional, with modern humans spreading rapidly through Central Europe, finally arriving on the Iberian Peninsula (Zilhão and d'Errico 1999).

\section{THE "EBRO-FRONTIER" AND RECENT CONTROVERSIES}

According to the European colonization scenario, anatomically modern humans reached the Iberian Peninsula last. Consequently, most authors today believe that modern humans - following the arrival of the Aurignacian north of the Ebro basin (as represented by the antiquity of early Aurignacian radiocarbon dates from the North of the Iberian Peninsula) - and Neanderthals in the southwestern part of the peninsula coexisted for many thousands of years: i.e. between 40.0 and 30.0 kyr ago (Fig. 2; Zilhão 2000a; 2000b; Zilhão and d'Errico 1999). In view of this "Ebro-Frontier"-model the Iberian Peninsula represents the major Neanderthal refugium (Vega Toscano 1993; vgl. Zilhão 1993) before their final replacement during the later Aurig- 


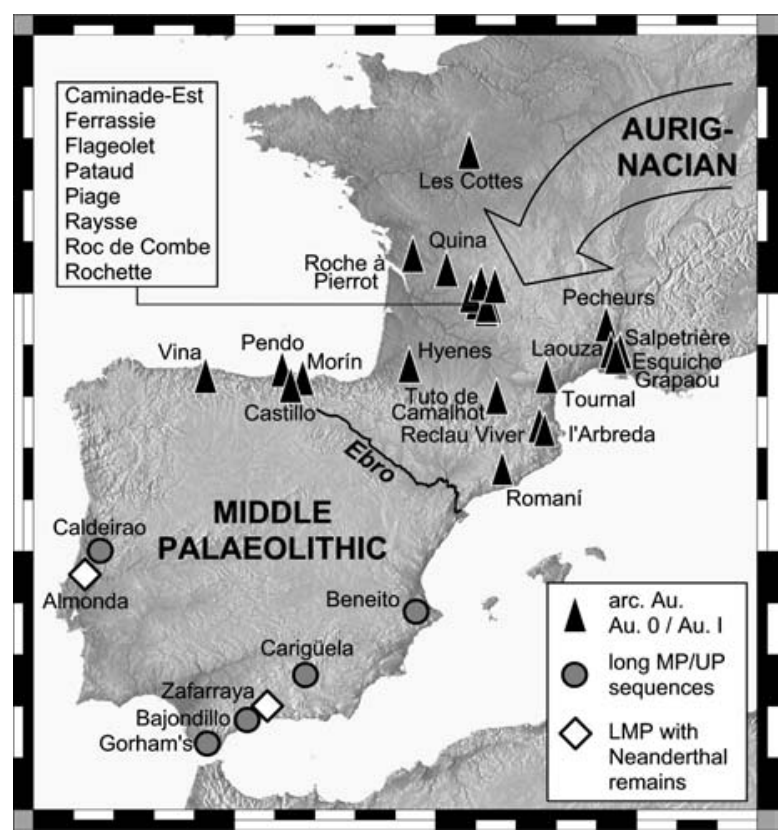

Fig. 2. J. Zihão’s “Ebro-Frontier”, seperating earliest anatomically modern human populations in Europe (as likely to be represented by 'archaic Aurignacian', 'Aurignacian 0' and 'Aurignacian I' inventories) from latest Middle Palaeolithic ones in the southwest of the Iberian Peninsula (modified after: Zilhão 2000a; 2000b; with addition from the "Stage Three Project database" of last interpleniglacial radiometric dates for European archaeological sites: Davies 2000, online; cf. annotation 1).

(arc.) Au. - (archaic) Aurignacian; MP - Middle Palaeolithic; UP - Upper Palaeolithic; LMP - Latest Middle Palaeolithic.

nacian, following ca. 33,500 ${ }^{14} \mathrm{C} \mathrm{BP}$ (Vega Toscano 1990; Zilhão 1993).

This paradigm of a quite recent colonization of Europe by anatomically modern humans has been challenged during recent years by an alternative model of an in situ development of the Aurignacian out of the preceding regional Latest Middle Palaeolithic (LMP), based on the results of new excavations at El Castillo cave (Cabrera Valdés et al. 2001).

Due to the nature of population advances and the sparse typological evidence (i.e. the dispersal of Aurignacian I type split-based points in the northern part of the Iberian Peninsula; cf. Zilhão 2000a; 2000b) the Ebro Frontier model relies to a great extent on methods of chronometric dating, each with its own implicit chronological notions. The alternative hypothesis of an Aurignacian in situ development in SW Europe is based on a series of chronometric data, most of which are also radiocarbon measurements.

In the present paper we have aimed to test the "Ebro-Frontier"-model and to evaluate the possibility of an Aurignacian in situ development, using the "Stage Three Project database" of last interpleniglacial (Oxygene Isotope Stage $3=$ OIS 3) radiometric dates for European archaeological sites (1), completed for the Iberian Peninsula as a part of assessments of the demographic processes underlying the transition from the LMP to the Earliest Upper Palaeolithic (EUP) in SW Europe.

\section{THE MIDDLE TO UPPER PALAEOLITHIC TRANSITION AND AURIGNACIAN ORIGINS}

Throughout the different regions of Europe, including its southwestern part, i.e. France and the Iberian Peninsula, regional archaeological records best displayed in numerous stratigraphies of cave sites and rock shelters, show exclusively Aurignacian industries post-dating LMP ones attributed to Neanderthals (Fig. 1). At several sites the latest MP is found in sediments formed under interstadial conditions of moderate to temperate climate attributed to the Hengelo-period (Carbonell et al. 2000), the most significant warm interval in the second half of OIS 3 (2).

In France and Northern Spain the Châtelperronian (3), which is restricted to these areas, is of-

(1) Davies 2000 (online): ARCH-DBASE.XLS at http:// www.esc.ac.uk/oistage3/secure/arch-dbase.xls (August 2000 with bibliography for the cited dates; cf. Tab. 1 and Tab. 2). Some further extended databases have been compiled by Bocquet-Appel and Demars (2000: http://intarch.ac.uk/antiquity/additional/ bocqtable1.html) and by d'Errico and Sánchez Goñi (2003 at QSR website: http://www.elsevier.nl/locate/quascirev), and Zilhão and d'Errico (1999).

(2) According to radiocarbon measurements available for Hengelo-interstadial deposits this warm interval most likely correlates with interstadial 12 of the Greenland ice cores (Greenland Interstadial $12=$ GI 12; Jöris 2003). This temperate intervall possibly continues until GI 11 (cf. Fig. 7).

(3) Besides the rich evidence of Châtelperronien in France (Bosinski 1987; Demars 1996), in Northern Spain, level 10 from Cueva Morín, the small inventories from Labeko Koba IX and Ekain X, and those from El Pendo and A Valiña with their stratigraphical problems (Maíllo Fernández 2003) are the only inventories known from Cantabria. From Catalunya only few Châtelperronian points have been recorded embedded in Aurignacian inventories (cf. Canal i Roquet and Carbonell i Roura 1989: 337: l'Arbreda, Cova Pau, Reclau Viver). Besides the problems concrening El Pendo (Montes Barquín and Sanguino González 2001), stratigraphical disturbances may also account to explain the interstratifications of Châtelperronian with Aurignacian levels at Roc de Combe (Rigaud 2001) and Le Piage in France (d'Errico et al. 1998; Rigaud 2001). 
ten sandwiched between LMP and Aurignacian layers (Carbonell et al. 2000; d'Errico et al. 1998). The few hominid fossil remains currently known may imply that the Châtelperronian should also to be linked to Neanderthals (Hublin et al. 1996; cf. Asmus 1964). Therefore, one may assign the Châtelperronian to the Middle Palaeolithic, as can be also argued from the evolution of lithic technology (Gouedo 1990; cf. Bodu 1990) and tool spectra (de Sonneville-Bordes 1972; Bosinski 1987; 1990), both showing links to LMP industries.

In summary, the MP/UP transition of SW Europe comprises a well-established sequence of LMP, Châtelperronian-, and EUP Aurignacian-type techno-complexes (Fig. 1).

\subsection{Radiocarbon evidence}

During recent years numerous chronometric dates have been assembled from a large number of sites dating to the LMP and EUP on the European continent (Bocquet-Appel and Demars 2000; Davies 2001). The dates have been compared and interpreted in context with archaeological findings (d'Errico and Sánchez Goñi 2003; Zilhão and d'Errico 1999) (4). Most of the dates, with radiocarbon-measurements forming the bulk of dates from the entire corpus of radiometric age-determinations, have been obtained from sites in SW Europe, alltogether providing more than 700 radiocarbon measurements $>17,500{ }^{14} \mathrm{C} \mathrm{BP}$, backed by more than 200 non-radiocarbon dates (TL/OSL; Useries; ESR). Due to its comprehensiveness the combined date list is a valuable instrument for studies on the demographic processes underlying the models in question.

However, due to a number of limitations of the different chronometric dating methods employed, in particular radiocarbon, caution in the meaning and interpretation of dates has repeatedly been expressed (e.g. Djindjian 1999; Pettitt 1999; Pettitt and Pike 2001). It is also most important to acknowledge that many of the ${ }^{14} \mathrm{C}$-measurements on which the MP/UP transition is based range close to the technical limits of the dating equipment. With increasing age the dates become, as a rule, less reliable (one of the principles of the method underlying radiocarbon dating). This is reflected in increas-

(4) See annotation 1. ing standard deviations as well as in the higher number of infinite ('greater than') age determinations - both parametres that largely depend on the technical equipment of the laboratory.

In the past developing radiocarbon methods did indeed produce a few dozen age determinations in the range of 10.0-12.5 half-lifes of radiocarbon. These were measured on large peat samples ( $c a$. $100 \mathrm{~g}$ carbon) by a combination of thermal isotope enrichment with large ${ }^{14} \mathrm{C}$ - $\beta$-counting systems (cf. Grootes 1977). Today, however, the technical limits of most modern laboratories for routine ${ }^{14} \mathrm{C}$ (AMS)-measurements remain close to 9.5 half-lifes i.e. ca. 55,000 ${ }^{14} \mathrm{CBP}$ (Fig. 3). While some radiocarbon laboratories promise reliability of their measurements up to at least 40,000 ${ }^{14} \mathrm{C} \mathrm{BP}$ (Hedges and Pettitt 1999), others have much lower technical age limits around 5.0-7.5 half-lives of radiocarbon age (5), i.e. the time of transition from LMP to EUP. Such problems principally effect radiocarbon dating and, consequently, the interpretation of dating results.

The most comprehensive study so far on the beginning of the EUP and the earliest occurences of the Aurignacian in Europe has been undertaken by Zilhão and d'Errico (1999) who, using a selected data set, (1) confirm the validity of the "EbroFrontier"-model and (2) state that no Aurignacian older than $36,500{ }^{14} \mathrm{C}$ BP (i.e. north of the Ebro basin) withstands their criteria of evaluation of sample taphonomy (6). This picture of earliest $\mathrm{Au}-$ rignacian presence in Europe results from the omission of all radiocarbon dates older than $36,500{ }^{14} \mathrm{C}$ BP on charcoal samples that appear systematically older relative to bone.

(5) Despite corresponding claims documented in the proposed analytical dating errors, we recognise that some radiocarbon laboratories, notably in earlier years, cannot achieve reproducible ${ }^{14} \mathrm{C}$-measurements of such high age. A fair portion of the equipment earlier used in B-decay counting quite apparently had rather large and at any rate often widely varying counter backgrounds, with statistical variations not always according to Poisson statistics, so that the reliability of the archaeological radiocarbon data available today is not in all cases beyond reasonable credence. Quality and reliability of dates thus relate to the age of the laboratory and the year a specific sample had been dated, rather than systematic offsets between conventional and mass spectrometric methods of radiocarbon dating as stated by d'Errico and Sánchez Goñi (2003).

(6) It is noteworthy that any dates are worthless without interpretation of the circumstances that may have contributed to the date, but the taphonomy and context of samples for radiometric dating are difficult to evaluate years after excavation. Any such 'evaluation' finally remains a selection judged by the authors' personal criteria. Testing the available data for integrity of their statistical properties should, at least, be carried out. 


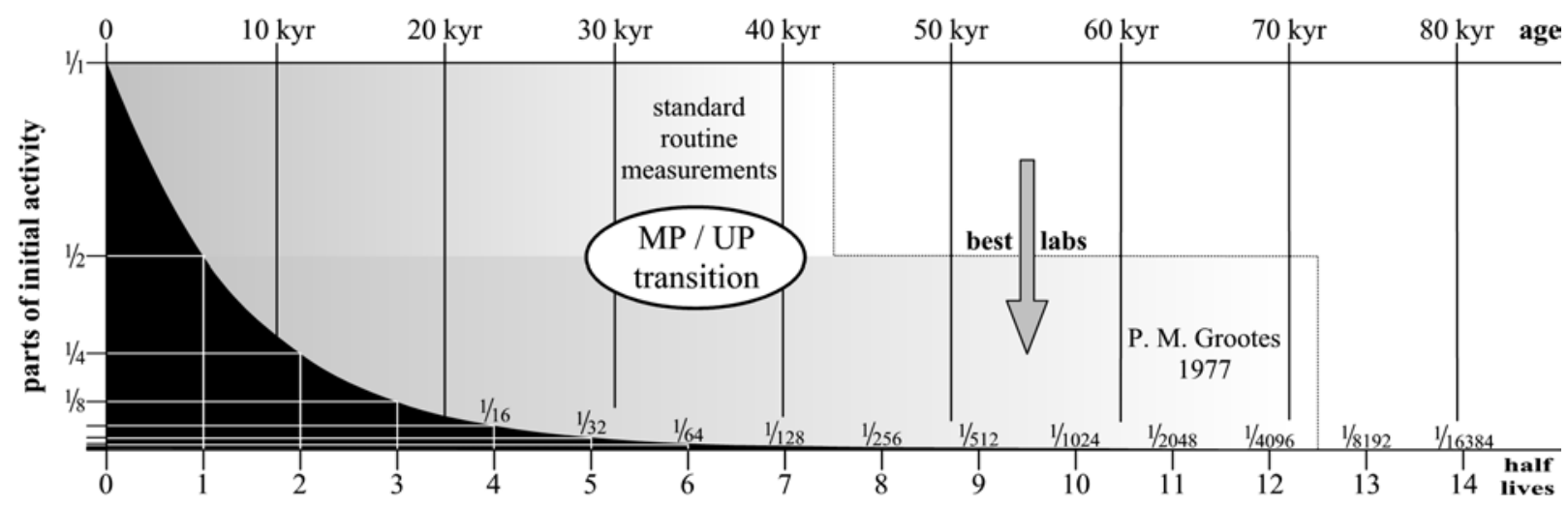

Fig. 3. Decay of radiocarbon with time relative to its initial activity in relation to the dating limits of radiocarbon laboratories. The Middle to Upper Palaeolithic transition (MP/UP) is close to the detection limits of most radiocarbon laboratories.

\subsection{A material matter}

In their analyses of data from the MP/UP transition Zilhão and d'Errico (1999) recognize that bone samples systematically turn out younger than charcoal ones, often diverging by several thousand ${ }^{14} \mathrm{C}$ BP. This phenomenon is independently and best illustrated by the example of the recently published ${ }^{14} \mathrm{C}$ data series from Kostienki 14 in Russia (Sinitsyn et al. 2002) (7). The main reason for Zilhão and d'Errico (1999) to trust the bone dates more than the ones produced from charcoal is that charcoal is often judged as 'mobile' material sensitive to stratigraphical disturbance, e.g. by processes of bioturbation. Based on the physical properties of the radiocarbon method of dating, there is no reason to rely more on the dating of bone rather than on charcoal samples, especially when the archaeological context is clearly identified, as is most likely to be the case with charcoal from hearths. For a variety of reasons, namely (1) the smaller initial content of datable carbon, (2) the well-known higher susceptibility of bone towards contamination with younger carbon, and (3) the disappearance of bone collagen due to decay (e.g. Schwarcz 2001), higher reliability should be given charcoal versus bone samples, especially when the samples are close to the detection limits of the radiocarbon method of dating.

Taken at face value, the ${ }^{14} \mathrm{C}$ age-distributions of

(7) At Kostienki 14 a layer of volcanic ash most likely to be linked with the Campanian Ignimbrite eruption (Fedele et al. 2002) confirms the great antiquity of charcoal data from the underlying strata, while horse bone samples show remarkable offsets towards younger ages (Sinitsyn et al. 2002). the MP and UP of SW Europe more or less overlap in the entire period from around 38,000 to 19,000 ${ }^{14} \mathrm{C} \mathrm{BP}$ (Fig. 4, left), creating a "Coexistence Effect" (Conard and Bolus 2003). This results from the exponentially decreasing rate of ${ }^{14} \mathrm{C}$-decay and the rapidly increasing susceptibility towards contaminaton in older samples, as shown by theoretical estimates of the surplus of modern carbon on dating (Grootes 1977). Due to the fact that the youngest LMP samples exclusively derive from samples of bone or burnt (cremated) bone, their young age-determinations are most likely due to effects of contamination and alterations of the physical properties of sample material during processes of combustion (cf. Schwarcz 2001; Gillespie 1997) and/or to difficulties in the techniques and methods of dating burnt bone (Lanting and Brindley 1999; cf. Gillespie 1997). It is often impossible to establish whether the material is contaminated or not, and apart from obvious anomalous samples, it is still difficult to judge until which age LMP dates may be considered reliable.

Having filtered for sample material type (i.e. bone versus charcoal), radiocarbon age-distributions for bone dates (Fig. 4, centre) appear similar to those that have already appeared in the entire data set, while a completely different picture of agedistributions is given with charcoal (Fig. 4, right). This is most clearly seen in MP charcoal dates that appear systematically older than those obtained on bone. Direct comparisons of both bone and charcoal samples, as undertaken exemplarily for the SW European MP on the one hand (Fig. 5, left) and the Aurignacian of the same region on the other (Fig. 5, centre; cf. Zilhão and d'Errico 1999), emphasize 


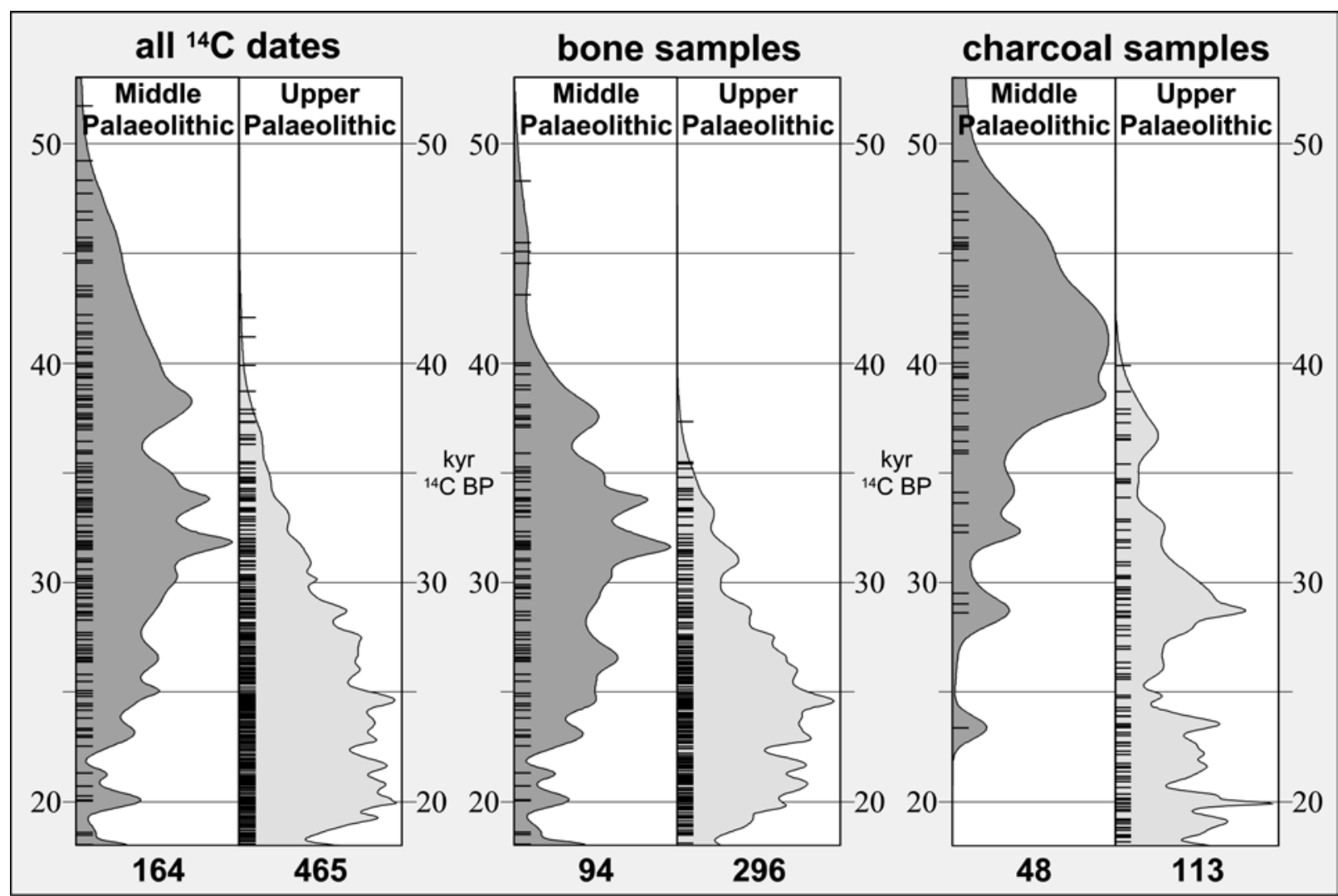

Fig. 4. Age-distributions $\left[\mathrm{kyr}{ }^{14} \mathrm{C} \mathrm{BP}\right]$ of Middle Palaeolithic (to the left of each diagram) radiocarbon-dates of SW Europe compared with those available for the Upper Palaeolithic (to the right of each diagram) of the same region comprising all ${ }^{14} \mathrm{C}$-data (left), those sorted for bone (center) and samples on charcoal (right).

In the construction method applied to the resulting ${ }^{14} \mathrm{C}$-dispersion graphs, each individual radiocarbon date has been defined by its given median value and standard deviation. The corresponding individual Gaussian curves have been added, to give a curve of the summed ${ }^{14} \mathrm{C}$ dating probability (Geyh 1969). Because each Gaussian curve is normalised with equal area, using this method each date/sample is given equal weight, independent of dating precision.

the complex difficulties with which radiocarbonbone samples are generally endowed (Jöris et al. 2001; Schwarcz 2001). Demographic modelling of the processes underlying the MP/UP transition (Fig. 5 , right) is thus strongly affected by the material dated.

\subsection{Aurignacian origins}

Against the background that different sample material may result in entirely different age-distributions, an 'alternative' radiocarbon chronology based solely on charcoal samples for the earliest occurences of the Aurignacian in Europe (1) pushes back earliest appearance of the Aurignacian to $c a$. $38,300{ }^{14} \mathrm{C} \mathrm{BP}$ and (2) produces two distinct geographical clusters of possible Aurignacian origin
(Fig. 6), i.e. the southeastern Central European region to the East and the Pyrenean and Cantabrian area to the SW (Jöris 2003). (3) The results do not, however, reflect a geographical pattern that one would assume in a model of anatomically modern humans colonizing Europe from the East to the West.

Since the Aurignacian lacks any readily apparent 'cultural predecessors' outside of Europe, it cannot be excluded that this culture may have evolved locally within these two regions in Europe (cf. Cabrera Valdés et al. 2001). The geographical dispersal of the oldest sites dated using ${ }^{14} \mathrm{C}$-charcoal samples could imply Aurignacian genesis out of LMP leaf-point industries in the East and out of the Châtelperronian in the SW. In these regions youngest reliable radiocarbon dates on charcoal for the LMP range between 38,800 and $35,900{ }^{14} \mathrm{CBP}$. 


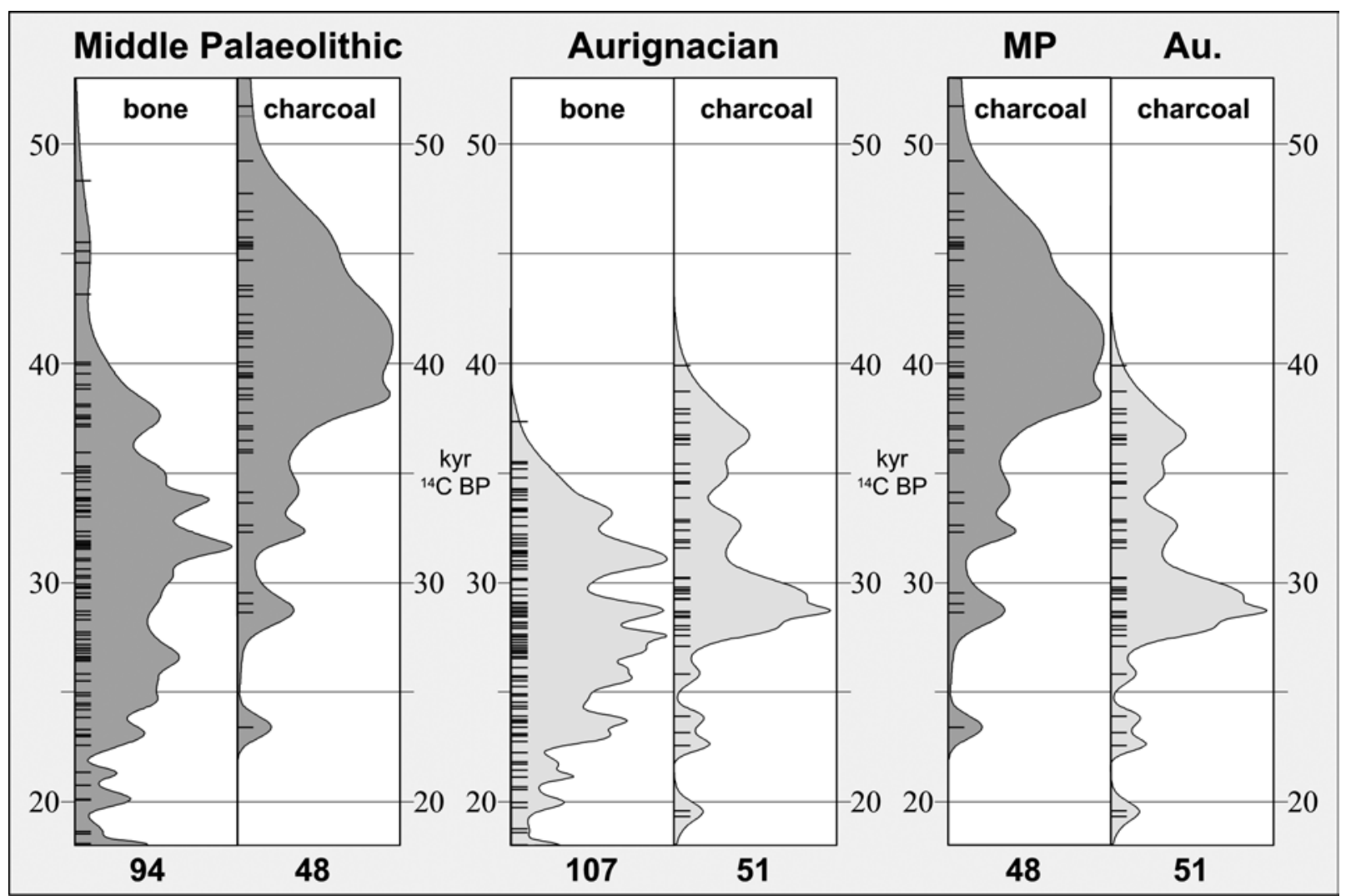

Fig. 5. Age-distributions $\left[\mathrm{kyr}{ }^{14} \mathrm{C} \mathrm{BP}\right]$ of radiocarbon samples on bone (to the left of the left and centre diagrams) compared with those derived from charcoal samples (to the right of the left and centre diagrams) for Middle Palaeolithic and Aurignacian technocomplexes in comparison with age-distributions based on charcoal samples (right) from the Middle Palaeolithic (MP) and Aurignacian (Au.).

In the construction method applied to the resulting ${ }^{14} \mathrm{C}$-dispersion graphs, each individual radiocarbon date has been defined by its given median value and standard deviation. The corresponding individual Gaussian curves have been added, to give a curve of the summed ${ }^{14} \mathrm{C}$ dating probability (Geyh 1969). Because each Gaussian curve is normalised with equal area, by this method each date/sample is given equal weight, independent of dating precision.

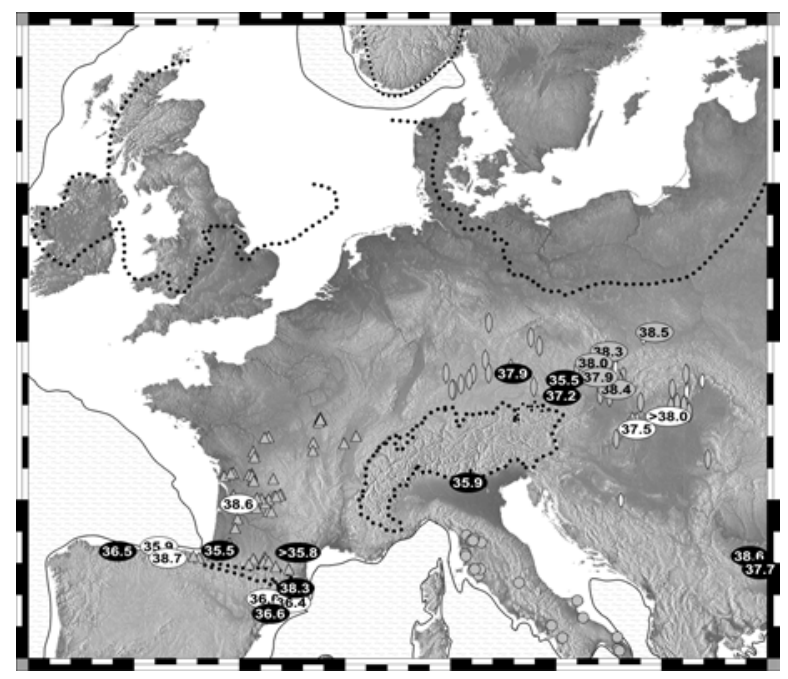

Fig. 6. Europe at the Middle to Upper Palaeolithic transition with Châtelperronian sites in the SW (Bosinski 1987; cf. Demars 1996), Uluzzian in Italy (Gioia 1990; Palma di Cesnola 1993), and leaf-point industries in south-central and southeastern Europe (Allsworth-Jones 1986; Bolus and Rück 2000) as well as 'last appearance data' (LAD's) for Middle Palaeolithic levels $<40,000$ and $>35,000{ }^{14} \mathrm{C} \mathrm{BP}$ (white underlain) and East European leaf-point industries (grey underlain) in comparison with first appearance data (FAD's) for the Aurignacian in Europe based on radiocarbon dates $>35,000{ }^{14} \mathrm{C} \mathrm{BP}$ (black underlain).

All radiocarbon FAD's and LAD's derive from charcoal samples and are given in $\mathrm{kyr}{ }^{14} \mathrm{C} \mathrm{BP}$, in case of repeated measurements given as weighted means (cf. Jöris 2003; cf. Tab. 1-2).

Palaeogeography of Europe corresponds to the glacial maximum of the last glaciation at around $22.5 \mathrm{kyr}$ cal BC with ice margins dotted and coastline lowered for some $120 \mathrm{~m}$. 


\section{THE EARLIEST AURIGNACIAN AND THE LATEST MIDDLE PALAEOLITHIC OF SOUTHWESTERN EUROPE}

The question of whether or not the Aurignacian originated from the regional LMP or is the result of anatomically modern humans colonizing Europe can best be approached from the point of view of available radiometric data (Tab. 1-2). In terms of this the "Ebro-Frontier"-model between ca. 40,000 and $30,000{ }^{14} \mathrm{C} \mathrm{BP}$ is testable, since it requires two basic lines of evidence, which are (1) proof for Aurignacian presence NE of the Ebro basin at times for which (2) contemporaneous LMP is manifested in

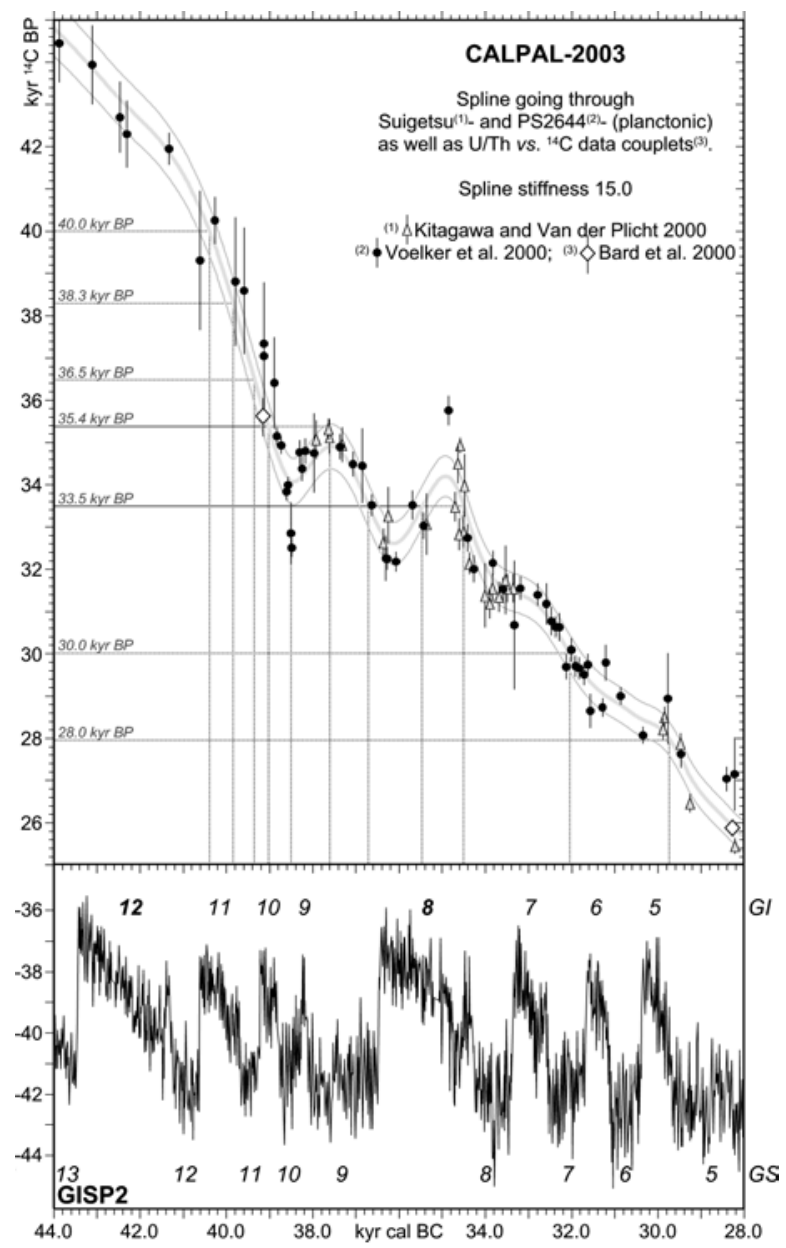

Fig. 7. Calibration of the radiocarbon scale $\left[\mathrm{kyr}{ }^{14} \mathrm{C} \mathrm{BP}\right]$ between 45,000 and $25,000{ }^{14} \mathrm{C} \mathrm{BP}$ (Jöris and Weninger 1999a; 1999b; 2000, updated; see annotation 8) in relation to the Greenland GISP2 ice core record $\left(\%\right.$ PDB $\delta^{18} \mathrm{O}$ after: Stuiver and Grootes 2000), in the time-window 44.0 $28.0 \mathrm{kyr}$ cal BC.

GI - Greenland interstadial; GS - Greenland stadial.

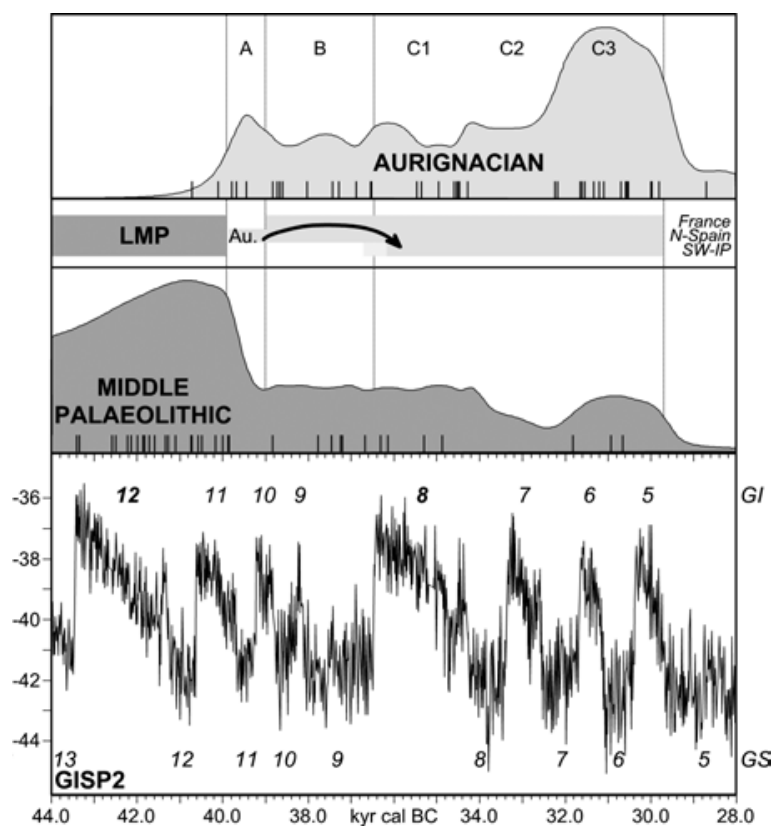

Fig. 8. Calibrated radiocarbon dates on charcoal of Middle Palaeolithic and Aurignacian of SW Europe (data identical with those in Fig. 5, right) against the GISP2 palaeoclimate record from Fig. 7, showing the abrupt ending of the Latest Middle Palaeolithic (LMP) at the onset of the Aurignacian (Au.) in SW Europe. For regional differences the Aurignacian is distinguished into A, B, C1, C2, C3.

the region SW. Both lines can contribute to the colonization model in question, assuming that LMP lithic industries indeed represent Neanderthals, and that anatomically modern humans are the artisans of the Aurignacian.

While first appearance data (FAD's) of the Aurignacian in Europe - based on ${ }^{14} \mathrm{C}$-charcoal samples - indeed demonstrate an early Aurignacian presence NE of the Ebro basin (Fig. 6), the second line of evidence is especially problematic to establish. Problems arise -as described in the preceding chapter-, in determining up to which age young LMP radiocarbon dates can still be regarded as reliable and, more importantly since only a few LMP sites in the southern part of the Iberian Peninsula are published in detail, with the exception of Gibraltar.

To derive 'realistic' latest-appearance estimates (LAD's) for LMP sites of that region, it is necessary to compare the radiocarbon dates availabe with nonradiocarbon age-determinations. But direct data pairs of different dating methods, radiocarbon versus non-radiocarbon, are unfortunately rare. Furthermore, it is necessary to acknowledge that the radiocarbon time-scale requires calibration to cor- 
rect for variations in past atmospheric ${ }^{14} \mathrm{C}$-levels (Fig. 7) (8) in order to achieve compatability with the results from other non-radiocarbon methods of dating. When calibrated, the ${ }^{14} \mathrm{C}$-time interval covering the MP/UP transition proposed by different authors roughly corresponds to the period 40.6 - 30.2 kyr cal BC (Tab. 3), showing a remarkably clear distinction between LMP versus Aurignacian age-distributions on the calendric scale (Fig. 8).

\subsection{Earliest Aurignacian evidence...}

The oldest Aurignacian sites in SW Europe dated by radiocarbon are situated in the North of the Iberian Peninsula (Fig. 2; Fig. 9). These sites - in sum - form the base of the first line of arguments for the "Ebro-Frontier"-model, stating that the Aurignacian starts around $36,500{ }^{14} \mathrm{C} \mathrm{BP}$ in most of $\mathrm{Eu}$ rope (Zilhão and d'Errico 1999), whereas the Aurignacian in the southwestern part of the Iberian Peninsula does not date before $33,500{ }^{14} \mathrm{C} \mathrm{BP}$ (Vega Toscano 1990; Zilhão 1993).

(8) We note, however, that all radiocarbon "age"-estimates are measured on the conventional ${ }^{14} \mathrm{C}$-scale, which is very precisely defined as a dimensionless logarithmic ratio (Mook 1983), so that an independent calibration of all ${ }^{14} \mathrm{C}$-ages is necessary if we wish to sensibly discuss the chronological implications of the ${ }^{14} \mathrm{C}$ data. Intensive progress in the construction of the calibration curves required for such age-transfer of (uncalibrated) radiocarbon dates into the calendric dimension has been made during the last few years (eg. Jöris and Weninger 1999a; 1999b; 2000; http:// www.calpal.de: CALPAL-2003; cf. van der Plicht 2002), with the period in question being best recorded in the data sets from Suigetsu in Japan (atmospheric; Kitagawa and van der Plicht 2000) and PS2644 in the North Atlantic (marine; Voelker et al. 2000). Between 46.0 and $28.0 \mathrm{kyr}{ }^{14} \mathrm{C}$ BP (45.0-30.0 kyr cal BC) the combined 'synthetical' calibration data set (CALPAL-2003) allows for rough calendric estimates of the ${ }^{14} \mathrm{C}$-time scale (Fig. 7), representing a pattern of highly fluctuating ${ }^{14} \mathrm{C}$-levels, with periods of extremely high production of radiocarbon (steep parts in the calibration curve), i.e. between 42.0 and $35.0 \mathrm{kyr}{ }^{14} \mathrm{C} \mathrm{BP}$, and others with limited production rates, resulting in long ${ }^{14} \mathrm{C}$-age-plateaux, i.e. between 39.0 and $35.0 \mathrm{kyr}$ cal BC, normally accompanied with extreme age-distortions (cf. Beck et al. 2001). It is this complex 'pattern' of the calibration curve that allows for improvement of dating precison for periods of rising atmospheric radiocarbon contents as well as the age-distortions which make it difficult to interpret radiocarbon dates that fall into the period of extended plateaux.

Due to the method of construction of the CALPAL-2003 record, i.e. the transferral of radiocarbon-dates from marine oxygene isotope records into the GISP2 Greenland ice core age model (Jöris and Weninger 1998; 1999a; 1999b; cf. Voelker et al. 1998; 2002), ${ }^{14} \mathrm{C}$-ages are reliably linked with palaeoclimate signatures (Fig. 7). This allows for high-precision age-transferral of ${ }^{14} \mathrm{C}$-measurements into a calendrical age-model, combined with its positioning within the record of OIS 3 palaeoclimate change that is characterised by extremely rapid oscillations between cold and dry (glacial) and more temperate (interstadial) conditions (for the Iberian Peninsula cf. Carbonell et al. 2000; d'Errico and Sánchez Goñi 2003).
Evidence for an Aurignacian presence in SW Europe dating prior to $36,500{ }^{14} \mathrm{C} \mathrm{BP}$ is sparse, and a single radiocarbon age on bone dated to $40,000 \pm$ $1400{ }^{14} \mathrm{C}$ BP (OxA-3727) obtained from the basal layer at Reclau Viver may be due to a reworked sample (Zilhão and d'Errico 1999). The upper part of the same level contains an Aurignacian I with split-based points (Canal i Roquet and Carbonell i Roura 1989). Similar problems seem to account for a radiocarbon measurement (GifA-97185: 37,200 $\pm 150{ }^{14} \mathrm{C} \mathrm{BP}$; bone) from layer $\mathrm{G}$ at Caminade-Est, where "systematic refitting work carried out by J.G. Bordes (1998) has demonstrated that around $30 \%$ of the archaeological material included in this layer comes from the underlying Mousterian deposits, to which the dated sample could conceivably be related" (Zilhão and d'Errico 1999, 17). The overlying layer $\mathrm{F}$ at this site has produced an Aurignacian I with split-based points, and a radiocarbon date of $35,400 \pm 1100{ }^{14} \mathrm{CBP}$ (GifA-97186) on bone (Rigaud 2001).

Whereas early Aurignacian sites are dispersed in SW France and Northern Spain (Fig. 2), oldest radiocarbon evidence for the Aurignacian (Tab. 1; Fig. 9) is exclusively restricted to the provinces of Cantabria and Catalunya in Northern Spain. Here the sites of Abric Romaní, L'Arbreda and El Castillo are most controversially discussed, due to their history of research, the antiquity of radiometric measurements with radiocarbon dates going back to $>36,500{ }^{14} \mathrm{C} \mathrm{BP}$, and typological arguments.

A series of radiocarbon measurements of charcoal samples from the new excavations of V. Cabrera Valdés immediately in front of the cave entrance at El Castillo gave results ranging between $41,100 \pm 1700(\mathrm{OxA}-2477)$ and 37,100 \pm 2200 (OxA-2473) ${ }^{14} \mathrm{C} \mathrm{BP}$ (Tab. 2) (Cabrera Valdés and Bischoff 1989; Cabrera Valdés et al. 1996, 2000; 2001) for a layer inside the cave labeled "Aurignacian Delta" by H. Obermaier (Cabrera Valdés 1984; cf. Cabrera Valdés et al. 1996). Zilhão and d'Errico (1999) critically request (1) the stratigraphic correlation of the layer outside the cave with the inner deposits, (2) the cultural attribution of the recent finds, and (3) the association of the samples dated with the lithic industry, which they think has more affinities with Mousterian or Châtelperronian than the Aurignacian. According to Zilhão and d'Errico (1999), the Aurignacian of El Castillo is present only inside the cave in the upper portion of Obermaiers "Aurignacian Delta", while the lower part of this layer contains more MP types, and likely 


\section{AURIGNACIEN > 33.5 kyr 14C BP and/or > 36.5 kyr non-14C BP}
LEVEL
CULTURE
WD
MAT. METH. LAB-NO.
DATE STD+ STD- $t$-val.

\section{C ON CHARCOAL}

\begin{tabular}{|c|c|c|c|c|c|c|c|c|}
\hline \multicolumn{9}{|c|}{ Gr. Tournal (Bize, Aude, France)] } \\
\hline G (sq. P31) & $\mathrm{Au}$. & 748 & charcoal & $14 \mathrm{C}$ & Ly-1898 & $>35800$ & & \\
\hline F (sq. LM32) & arc. Au. & 746 & charcoal & $14 \mathrm{C}$ & Ly-1895 & $>29000$ & & \\
\hline C (sq. L31) & arc. Au. & 747 & charcoal & $14 \mathrm{C}$ & Ly-1031 & $>34200$ & & \\
\hline \multicolumn{9}{|c|}{ Esquicho-Grapaou (Sainte-Anastasie, Gard, France) } \\
\hline SCL1B & Au. 0 & 372 & charcoal & $14 \mathrm{C}$ & MC-2161 & 34540 & 2000 & 2000 \\
\hline \multicolumn{9}{|c|}{ Isturitz (Saint-Martin-d'Aberoue, Pyrénées Atlantiques, France) } \\
\hline V1 26 & $\mathrm{Au}$. & 708 & charcoal & $14 \mathrm{C}$ & GifA-98233 & 34630 & 560 & 560 \\
\hline \multirow[t]{2}{*}{$\mathrm{U} 27,4 \mathrm{~d}$} & $\mathrm{Au}$. & 707 & charcoal & $14 \mathrm{C}$ & GifA-98232 & 36510 & 610 & 610 \\
\hline & $A u$. & $707-708$ & charcoal & $14 C$ & weighted mean & 35490 & 413 & \\
\hline \multicolumn{9}{|c|}{ La Vina (Manzaneda, Asturias, Spain) } \\
\hline XIII inf. & $\mathrm{Au} . \mathrm{I}$ & 92 & charcoal & $14 \mathrm{C}$ & Ly-6390 & 36500 & 750 & 750 \\
\hline
\end{tabular}

\section{C on CHARCOAL vs. $14 \mathrm{C}$ on BONE}

\begin{tabular}{|c|c|c|c|c|c|c|c|c|c|}
\hline \multicolumn{10}{|c|}{ L'Arbreda (Serinyà, Girona, Spain) } \\
\hline CE 103 [Level H] & $\mathrm{Au}$. & 151 & bone & $14 \mathrm{C}$ & OxA-3729 & 37340 & 1000 & 1000 & \\
\hline B1 [Level H] sq. E2 & arc. Au. & 147 & charcoal & $14 \mathrm{C}$ & AA-3779 & 37700 & 1000 & 1000 & 0,53 \\
\hline B1 [Level H] sq. E2 & arc. Au. & 148 & charcoal & $14 \mathrm{C}$ & AA-3780 & 37700 & 1000 & 1000 & 0,53 \\
\hline B1 [Level H] sq. E2 & arc. Au. & 150 & charcoal & $14 \mathrm{C}$ & AA-3782 & 38700 & 1200 & 1200 & 0,30 \\
\hline B1 [Level H] sq. E2 & arc. Au. & 149 & charcoal & $14 \mathrm{C}$ & AA-3781 & 39900 & 1300 & 1300 & 1,13 \\
\hline B1 [Level H] sq. E2 & arc. $A u$. & $147-150$ & charcoal & $14 C$ & weighted mean & 38307 & 552 & & \\
\hline BE 111 [Level H] & arc. Au. & 152 & bone & $14 \mathrm{C}$ & OxA-3730 & 35480 & 820 & 820 & \\
\hline
\end{tabular}

\section{C on CHARCOAL vs. 14C on UNKNOWN MATERIAL}

$\begin{array}{lcccccrrr}\text { Beneito (Muro, Alicante, Spain) } & & & & & & \\ \text { VIII } & \text { Au. } & 160 & ? & 14 C & \text { Gif-7650 } & 26040 & 890 & 890 \\ \text { VIII } & \text { Au. } & 159 & \text { charcoal } & 14 C & \text { AA-1388 } & 33900 & 1100 & 1100\end{array}$

\section{C on CHARCOAL vS. U-SERIES}

\begin{tabular}{|c|c|c|c|c|c|c|c|c|c|}
\hline \multicolumn{10}{|c|}{ Romani (Capellades, Barcelona, Spain) } \\
\hline above lev. 2 & & 142 & charcoal & $14 \mathrm{C}$ & USGS-2839 & 36600 & 1300 & 1300 & \\
\hline 2 & arc. Au. & 135 & charcoal & $14 \mathrm{C}$ & AA-8037A* & 35400 & 810 & 810 & \\
\hline 2 & arc. Au. & 136 & charcoal & $14 \mathrm{C}$ & AA-8037B* & 37900 & 1000 & 1000 & \\
\hline 2 & arc. Au. & $135-136$ & charcoal & $14 \mathrm{C}$ & weighted mean* & 36390 & 629 & & 0,35 \\
\hline 2 & arc. Au. & 137 & charcoal & $14 \mathrm{C}$ & NZA-2311 & 36590 & 640 & 640 & 0,07 \\
\hline 2 & arc. Au. & 141 & charcoal & $14 \mathrm{C}$ & AA-6608 & 36740 & 920 & 920 & 0,10 \\
\hline 2 & arc. Au. & 140 & charcoal & $14 \mathrm{C}$ & AA-7395 & 37290 & 990 & 990 & 0,61 \\
\hline 2 & arc. Au. & all level 2 & charcoal & $14 C$ & weighted mean & 36644 & 373 & & \\
\hline 2 & arc. Au. & 144 & travertine & U-series & $?$ & 43000 & 1000 & 1000 & \\
\hline below lev. 2 & & 143 & charcoal & $14 \mathrm{C}$ & $\begin{array}{l}\text { USGS-2840 } \\
*=\text { identical sample }\end{array}$ & 35000 & 500 & 500 & \\
\hline
\end{tabular}

\section{$14 \mathrm{C}$ on BONE}

\begin{tabular}{|c|c|c|c|c|c|c|c|c|c|}
\hline \multicolumn{10}{|c|}{ Flageolet I (Bézenac, Dordogne, France) } \\
\hline $\mathrm{XI}$ & Au. I & 321 & bone & $14 \mathrm{C}$ & Ly-2727 & $>31500$ & & & \\
\hline $\mathrm{XI}$ & Au. I & 323 & bone & $14 \mathrm{C}$ & GifA-95538 & 32040 & 850 & 850 & 0,90 \\
\hline $\mathrm{XI}$ & Au. I & 320 & bone & $14 \mathrm{C}$ & OxA-598 & 33800 & 1800 & 1800 & 0,42 \\
\hline $\mathrm{XI}$ & Au. I & 322 & bone & $14 \mathrm{C}$ & GifA-95559 & 34300 & 1100 & 1100 & 1,03 \\
\hline$X I$ & Au. I & $320+322-23$ & bone & $14 C$ & weighted mean & 32997 & 630 & & \\
\hline \multicolumn{10}{|c|}{ Pataud (Les-Eyzies-de-Tayac, Dordogne, France) } \\
\hline 14 & Au. 0 & 258 & burnt bone & $14 \mathrm{C}$ & GrN-4610 & 33300 & 760 & 760 & 0,28 \\
\hline 14 & Au. 0 & 259 & bone & $14 \mathrm{C}$ & GrN-4720 & 33330 & 410 & 410 & 0,38 \\
\hline 14 & Au. 0 & 257 & burnt bone & $14 \mathrm{C}$ & GrN-4507 & 34250 & 675 & 675 & 0,97 \\
\hline 14 & $A u .0$ & $257-259$ & & $14 C$ & weighted mean & 33529 & 318 & & \\
\hline
\end{tabular}

Tab 1. 


\begin{tabular}{|c|c|c|c|c|c|c|c|c|}
\hline \multicolumn{9}{|c|}{ Mollet (Serinyà, Girona, Spain) } \\
\hline $0.6-0.8 \mathrm{~m}$ & Au. & 158 & bone & $14 \mathrm{C}$ & OxA-3728 & 33780 & 730 & 730 \\
\hline \multicolumn{9}{|c|}{ Combe Sauniere (Sarliac-sur-I'Isle, Dordogne, France) } \\
\hline VIII & Au. & 724 & bone & $14 \mathrm{C}$ & OxA-6507 & 34000 & 850 & 850 \\
\hline \multicolumn{9}{|c|}{ Caminade (La Canéda, Dordogne, France) } \\
\hline $\mathrm{D} 21$ & Au. II & 450 & bone & $14 \mathrm{C}$ & GifA-97187 & 34140 & 990 & 990 \\
\hline \multicolumn{9}{|c|}{ Roc de Combe (Payrignac, Lot, France) } \\
\hline $7 \mathrm{c}$ & Au.I & 433 & bone & $14 \mathrm{C}$ & OxA-1263 & 34800 & 1200 & 1200 \\
\hline \multicolumn{9}{|c|}{ Castanet (Sergeac, Dordogne, France) } \\
\hline inferieur & $\mathrm{Au}$. & 712 & bone & $14 C$ & GifA-97313 & 35200 & 1100 & 1100 \\
\hline \multicolumn{9}{|c|}{ Caminade (La Canéda, Dordogne, France) } \\
\hline $\mathrm{F}$ & Au. I & 448 & bone & $14 \mathrm{C}$ & GifA-97186 & 35400 & 1100 & 1100 \\
\hline \multicolumn{9}{|c|}{ Caminade (La Canéda, Dordogne, France) } \\
\hline G & Au. I? & 449 & bone & $14 \mathrm{C}$ & GifA-97185 & 37200 & 1500 & 1500 \\
\hline \multicolumn{9}{|c|}{ Reclau Viver (Serinyà, Girona, Spain) } \\
\hline T III & arc. Au.? & 165 & bone & $14 \mathrm{C}$ & OxA-3727 & 40000 & 1400 & 1400 \\
\hline
\end{tabular}

\section{$14 \mathrm{C}$ on BONE vs. 14C on UNKNOWN MATERIAL}

\begin{tabular}{|c|c|c|c|c|c|c|c|c|}
\hline \multicolumn{9}{|c|}{ Tuto de Camalhot (Saint-Jean-des-Verges, Ariège, France) } \\
\hline & Au. I? & 156 & bone & $14 \mathrm{C}$ & Gif-2941 & 24200 & 600 & 600 \\
\hline & Au. I & & $?$ & $14 \mathrm{C}$ & $?$ & 34750 & 570 & 570 \\
\hline \multicolumn{9}{|c|}{ Ferrassie (Savignac-de-Miremont, Dordogne, France) } \\
\hline K6 & Au. I & 344 & $?$ & $14 \mathrm{C}$ & GrN-5751 & 33220 & 570 & 570 \\
\hline K6 & Au. I & 343 & bones & $14 C$ & Gif-4279 & $>35000$ & & \\
\hline
\end{tabular}

\section{C ON UNKNOWN MATERIAL}

\begin{tabular}{|c|c|c|c|c|c|c|c|c|c|}
\hline \multicolumn{10}{|c|}{ Arenillas (Cantabria, Spain) } \\
\hline II & $\mathrm{Au}$. & 87 & $?$ & $14 \mathrm{C}$ & $\mathrm{GrN}-?$ & 33870 & 1700 & 1700 & 0,20 \\
\hline II & $\mathrm{Au}$. & 88 & $?$ & $14 \mathrm{C}$ & $\mathrm{GrN}-?$ & 34660 & 1600 & 1600 & 0,19 \\
\hline II & $A u$. & $87-88$ & ? & $14 C$ & weighted mean & 34289 & 1165 & & \\
\hline \multicolumn{10}{|c|}{ Pataud (Les-Eyzies-de-Tayac, Dordogne, France) } \\
\hline$?$ & Au. I & 265 & ? & $14 \mathrm{C}$ & $\mathrm{GrN}-3230$ & 34760 & 1000 & 1000 & \\
\hline
\end{tabular}

\section{TL / OSL}

\section{Gato Preto (Rio Maior, Santarém, Portugal)}

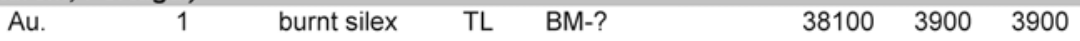

Tab 1 (Cont.). Radiometric dates for the SW European Aurignacian. WD - No. in William Davies datelist (see annotation 1); MAT. - material dated; METH. - dating method; STD - standard deviation; $t$-val . - t-value. (arc.) Au. - (archaic) Aurignacian.

correlates with layer 18 of V. Cabrera Valdés' excavation. Due to the fact that Obermaier did not observe a sterile horizon between the upper and lower portions of the "Aurignacian Delta"-sediment, one may conclude that the Aurignacian immediately followed $38,679 \pm 744{ }^{14} \mathrm{C} \mathrm{BP}$, which is the weighted mean (WM) of five radiocarbon measurements on charcoal samples from sub-unit b of layer 18 . The underlying $s u b$-unit $\mathrm{c}$ has produced five additional radiocarbon dates- again all on charcoal - resulting in a WM of $40,621 \pm 750{ }^{14} \mathrm{C} \mathrm{BP}$ paired with three ESR dates on bone (Rink et al. 1996; WM: $38.4 \pm 2.6 \mathrm{kyr} \mathrm{BP}$ ).

However, a consistent group of radiocarbon agedeterminations (Tab. 1), significantly older than $36,500{ }^{14} \mathrm{C} \mathrm{BP}$, has been produced for the Aurigna- cian layers of L'Arbreda (Bischoff et al. 1989; Canal i Roquet and Carbonell i Roura 1989). Four charcoal samples taken in an artificial $5 \mathrm{~cm}$-horizon (5,50-5,55m below surface) in square E2 (BE 111) immediately sheltered by the travertine wall in the lower Aurignacian, have produced a WM of 38,307 $\pm 552{ }^{14} \mathrm{C} \mathrm{BP}$ (Bischoff et al. 1989). Furthermore a radiocarbon measurement of $35,480 \pm 820{ }^{14} \mathrm{C} \mathrm{BP}$ (OxA-3730) on bone assigned to the same cultural unit is available. A few metres to one side (CE 103) a radiocarbon measurement, again on bone, ages the upper Aurignacian level to $37,340 \pm 1000{ }^{14} \mathrm{C}$ BP(OxA-3729), whereas one further measurement (Gif-6422) obtained earlier, is considered to be too young. Against the homogeneity of the available data we can hardly follow the vague assumptions of 


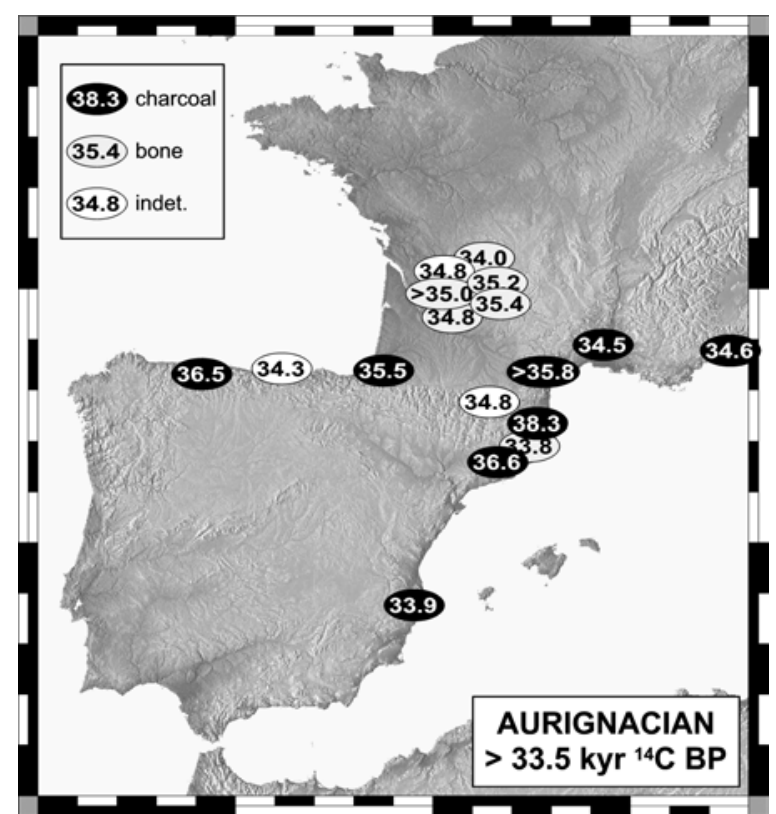

Fig. 9. Radiocarbon dates (first appearance data: FAD's) for the SW European Aurignacian, sorted for material dated and given in $\mathrm{kyr}^{14} \mathrm{C} \mathrm{BP}$, when required as weighted means.

Zilhão and d'Errico (1999) who claim possible stratigraphical disturbances in the various parts of the area excavated, and cannot assign the spatial origin of samples to areas that may be stratigraphically problematic. On the contrary:The samples from square E2 come from the very base of the Aurignacian deposits, immediately next to the main profile published by Canal i Roquet and Carbonell i Roura (1989).

Although the Aurignacian of L'Arbreda displays some similarities with that of "layer 2" at Abric Romaní (e.g. in terms of the presence of Dufour bladelets; Carbonell et al. 2000, 18), G. Laplace and N. Soler have emphasized the likelihood that the small assemblage from this layer may have resulted out of palimpsests of different occupations, one during the late Gravettian, another during the Aurignacian, based on the similarities of some (6) backed tools with Gravettian points (Canal i Roquet and Carbonell i Roura 1989; Carbonell et al. 1994). This 'Aurignacian' layer from the initial excavations conducted by A. Romaní between 1909 and 1929 ("layer 2") is preserved in remnant deposits - labeled "level $A$ " - along the back wall of the central part of the rock-shelter as well as in the Coveta Nord, where it is stratified between two travertine horizons (Bischoff et al. 1994). "Level A" - al- though only $2 \mathrm{~cm}$ in thickness - produced "abundant faunal remains, dispersed charcoal and artifacts" (Bischoff et al. 1994: 544) and most likely represents a living floor sealed by the overlying travertine. Seven radiocarbon measurements on charcoals were obtained from the remnant "level A" deposits at three different places of the site all together. Five of these form a WM of 36,644 \pm 373 ${ }^{14} \mathrm{C} \mathrm{BP}$, with individual dates ranging from 37,290 \pm 990 (AA-7395) to $36,390 \pm 629$ (WM of AA8037A and AA-8037B) ${ }^{14} \mathrm{C} \mathrm{BP}$. These dates are in strong contrast to two measurements from the radiocarbon laboratory in Waikato, New Zealand, which - due to possible contamination with younger carbon - are significantly younger (NZA1817; NZA-1818). The same laboratory has also produced a date of $36,590 \pm 640{ }^{14} \mathrm{C} \mathrm{BP}$ (NZA2311 , contained in the WM given above). All these dates are stratigraphically consistent with a further radiocarbon measurement of a charcoal sample that was embedded in the travertine (USGS-2839: $36,600 \pm 1300{ }^{14} \mathrm{C} \mathrm{BP}$; Bischoff et al. 1994). Furthermore, the great antiquity of these deposits is confirmed by U-series dating of this travertine (Bischoff et al. 1994; with corrected U/Th-ages of between 39.1 and $42.9 \mathrm{kyr}$ BP given in Carbonell et al. 1994) (9). Concerning the difficulties with the archaeological assignment of "layer 2" Zilhão and d'Errico (1999), plead for the stratigraphical reliability of this sequence. Whereas it is highly likely that the radiocarbon measurements from "level $A$ " material do indeed date the Aurignacian, stratigraphical mixing on top of the Aurignacian layer may also have played a role, close to the wall of the rock-shelter, and only a few metres away from the sampled area (as observed by A. Romaní).

Contra the interpretation of Zilhão and d'Errico (1999) the evidence from Castillo, L'Arbreda, and Romaní strongly indicates earliest Aurignacian presence in the North of the Iberian Peninsula before $36,500{ }^{14} \mathrm{C} \mathrm{BP}$ (Fig. 10), confirmed by the constistency of both radiometric dating and stratigraphy. Insignificantly younger radiocarbon measurements - all on charcoal - derive from the lower part of layer XIII at La Viña (Ly-6390: 36,500 \pm $750{ }^{14} \mathrm{C} \mathrm{BP}$ ), from Isturitz (WM of two dates: $35,490 \pm 413{ }^{14} \mathrm{C} \mathrm{BP}$ ), and possibly at Tournal G (oldest date: Ly-1898: >35,800 ${ }^{14} \mathrm{C} \mathrm{BP}$ ).

(9) Although less precise than radiocarbon dates, due to the high standard deviations, the results from U-series dating at Romaní approximately fit the ranges of the calibrated radiocarbon measurements (cf. CALPAL-2003: http://www.calpal.de). 


\begin{tabular}{|c|c|c|}
\hline CASTILLO & L'ARBREDA & ROMANÍ \\
\hline \multirow[b]{3}{*}{ Au. I: level 18 ('inner') } & \multirow[b]{2}{*}{$\begin{array}{l}\text { Au.: CE } 103 \\
37,340 \pm 1000{ }^{44} \mathrm{C} \text { BP }\end{array}$} & $\begin{array}{l}\text { above level } 2 \\
36,600 \pm 1300{ }^{14} \mathrm{C} \text { BP }\end{array}$ \\
\hline & & $\begin{array}{l}\text { arc. Au.: level } 2 \\
36,644 \pm 373{ }^{14} \mathrm{C} \text { BP }\end{array}$ \\
\hline & $\begin{array}{l}\text { arc. Au.: B1 } \\
38,307 \pm 552{ }^{14} \mathrm{C} \text { BP }\end{array}$ & AURIGNACIAN \\
\hline \multirow{2}{*}{$\begin{array}{l}\text { LMP: level } 18 \text { ('outer') } \\
38,679 \pm 7444^{14} \mathrm{C} \text { BP }\end{array}$} & \multicolumn{2}{|c|}{ MIDDLE PALAEOLITHIC } \\
\hline & $\begin{array}{l}\text { LMP: BE } 116 \\
40,267 \pm 1054{ }^{14} \mathrm{C} \text { BP }\end{array}$ & $\begin{array}{l}\text { LMP: level } 4 \\
43,500 \pm 1200{ }^{n} \mathrm{C} \text { BP }\end{array}$ \\
\hline
\end{tabular}

Fig. 10. Aurignacian (Au.) and archaic Aurignacian (arc. Au.) $>36,500{ }^{14} \mathrm{C}$ BP in the northern part of the Iberian Peninsula and its relation to Latest Middle Palaeolithic (LMP) industries.

Towards the North (north of $44.0^{\circ} \mathrm{N}$; Fig. 9) radiocarbon FAD's of the oldest regional Aurignacian turn out slightly younger (starting with 35,400 \pm $1100{ }^{14} \mathrm{C}$ BP [GifA-97186] in layer F of CaminadeEst; Tab. 1), and in the south of the Iberian Peninsula, the oldest Aurignacian is present in Beneito VIII (AA-1388: 33,900 $\pm 1100{ }^{14} \mathrm{C} \mathrm{BP}$ on charcoal). Further to the South and to the West radiocarbon dates for the Aurignacian are even younger than 33,500 ${ }^{14}$ C BP (Vega Toscano 1990; Zilhão 1993), with the Portugese site of Gato Preto, dated by TL to $38.1 \pm 3.9 \mathrm{kyr} \mathrm{BP}$, representing the oldest Aurignacian in the SW of the Iberian Peninsula.

\section{2. ... and evidence for the latest Middle Palaeolithic}

For SW Europe the "Ebro-Frontier"-model assumes LMP industries at times when Aurignacian people had already populated the North and Northeast of the Iberian Peninsula (Zilhão 1993; cf. Fig. 2). For the second line of arguments underlying the "Ebro-Frontier"-model it is thus important to verify the contemporaneity of LMP industries in the SW of the Iberian Peninsula with the earliest Aurignacian in the North and Northeast, i.e. evidence persisting significantly later than $38,300{ }^{14} \mathrm{C}$ BP. This is all the more difficult since Aurignacian layers in general overlay LMP ones and are subject to some reworking of deposits. Relying more on ${ }^{14} \mathrm{C}$-bone data for the MP/UP transition, Zilhão and d'Errico (1999: 10) note the "apparent contradiction between stratigraphy and dating" because the radiometric dates do imply a significant chronological overlap. They try to explain this contradiction as "simply an artifact of serious errors of method and interpretation in the use of radiometric results".

Due to the problems of possible sample contamination and the fact that - as a trend - radiocarbon charcoal data are shown to be more reliable than bone data, we will base our study solely on radiocarbon dates on charcoal as well as on the chronometric data available from the different non-radiocarbon methods of dating (e.g. TL/OSL, U-series; ESR, Tab. 2; Fig. 11), in order to trace reliable LMP LAD's in SW Europe

Regarding the charcoal-dated LMP (incl. Châtelperronian) of SW Europe only two sites Fuentes de San Cristobal (Mousterian) and Morín (layer 10: Châtelperronian) - have produced finite radiocarbon age-determinations younger than $38,300{ }^{14} \mathrm{C}$ BP. At Morín the same sample (SI-951) has produced two contradictory radiocarbon measurements, one with an extremely high standard deviation of several thousand BP. These measurements along with a single sample (OxA-8591) for the LMP at Fuentes de San Cristobal with a high standard deviation $( \pm 1900)$, cannot be interpreted as reliable proof for a long persistence of the LMP in SW-Europe.

One sample from the basal LMP layer $\mathrm{X}$ at Beneito in the SE of the Iberian Peninsula has been dated to $30,160 \pm 680{ }^{14} \mathrm{C} \mathrm{BP}$ (unknown lab.-no.), whereas a second sample (AA-1387) on charcoal, obtained from the same layer, dates to $38,800 \pm$ $1900{ }^{14} \mathrm{C} \mathrm{BP}$ and is thus similar in age to the WM of the radiocarbon measurements available for the LMP layer $18 b$ of El Castillo $(38,679 \pm 744)$. Sample AA-1388 from the overlaying Aurignacian level VIII at Beneito confirms the antiquity of the AA1387 sample.

Other sites that have produced radiocarbon agedeterminations younger than $38,300{ }^{14} \mathrm{C}$ BP have either been dated several decades ago (e.g. Ermitons, Quinçay, Tournal, Brugas) or the dates have been obtained from "inadequate dating material" (Zilhão 2000a: e.g. Columbeira) that is likely to be contamined with modern carbon (Zilhão 1997: 35). Possible contamination is furthermore likely for some radiocarbon measurements from LMP layers that have been independently dated by non-radiocarbon methods. At Zafarraya (Hublin et al. 1995), for example, teeth of Capra ibex were dated by radiocarbon as well as by U-series methods, but due to a variety of reasons mostly related to the stratigraphical properties of this site, these samples are 


\section{MIDDLE PALAEOLITHIC < 40.0 kyr 14C BP and/or < 43.5 kyr non-14C BP}
LEVEL
CULTURE
WD
MAT. METH. LAB-NO.
DATE STD+ STD- $t$-val.

14C on CHARCOAL

\begin{tabular}{|c|c|c|c|c|c|c|c|c|c|}
\hline \multicolumn{10}{|c|}{ St-Marcel (Bidon, Ardèche, France) } \\
\hline G2 & MP & 761 & charcoal & $14 \mathrm{C}$ & Ly-2901 & $>25000$ & & & \\
\hline \multicolumn{10}{|c|}{ Devil's Tower (Gibraltar) } \\
\hline 3 & MP & 256 & charcoal & $14 \mathrm{C}$ & $\mathrm{GrN}-2488$ & $>30000$ & & & \\
\hline \multicolumn{10}{|c|}{ Trozoul (Trébeurden, Bretagne, France) } \\
\hline hearth & MP? & 505 & charcoal & $14 \mathrm{C}$ & Gif-1312 & $>35000$ & & & \\
\hline \multicolumn{10}{|c|}{ Los Moros I (Gabasa, Huesca, Spain) } \\
\hline a & MP & * & charcoal & $14 \mathrm{C}$ & OxA-5671 & $>39000$ & & & \\
\hline$a+c$ & MP & * & charcoal & $14 \mathrm{C}$ & OxA-5672 & $>45000$ & & & \\
\hline \multicolumn{10}{|c|}{ * = Blasco Sánchez and Montes Ramírez 1997} \\
\hline \multicolumn{10}{|c|}{ Cueva Morin (Villanueva, Villaescusa, Cantabria, Spain) } \\
\hline 10 & Chat. & 100 & charcoal & $14 \mathrm{C}$ & SI-951* & 27777 & 577 & 577 & \\
\hline 10 & Chat. & 99 & charcoal & $14 \mathrm{C}$ & $\begin{array}{l}\text { SI-951- } \mathrm{A}^{\star} \\
{ }^{\star}=\text { identical sample }\end{array}$ & 35874 & 6777 & 6777 & \\
\hline \multicolumn{10}{|c|}{ Fuentes de San Cristobal (Veracruz, Huesca, Spain) } \\
\hline & MP & * & charcoal & $14 \mathrm{C}$ & OxA-8591 & 36000 & 1900 & 1900 & \\
\hline \multicolumn{10}{|c|}{${ }^{*}=$ Rosell Ardèvol et al. 2000} \\
\hline \multicolumn{10}{|c|}{ Barbas III (Creysse, Dordogne, France) } \\
\hline 4 & MP & 731 & charcoal & $14 \mathrm{C}$ & $?$ & 38300 & 500 & 500 & 0,37 \\
\hline 4 & MP & 732 & charcoal & $14 \mathrm{C}$ & GifA-93050 & 43500 & 2200 & 2200 & 2,19 \\
\hline 4 & $M P$ & $731-732$ & charcoal & $14 C$ & weighted mean & 38555 & 488 & & \\
\hline \multicolumn{10}{|c|}{ Castillo (Puente Viesgo, Cantabria, Spain) } \\
\hline 18b-upper & MP & 124 & charcoal & $14 \mathrm{C}$ & AA-2407 & 37700 & 1800 & 1800 & 0,50 \\
\hline 18b-upper & MP & 123 & charcoal & $14 \mathrm{C}$ & AA-2406 & 38500 & 1800 & 1800 & 0,09 \\
\hline $18 \mathrm{~b}$ & MP & 127 & charcoal & $14 \mathrm{C}$ & OxA-2473 & 37100 & 2200 & 2200 & 0,68 \\
\hline $18 b$ & MP & 126 & charcoal & $14 \mathrm{C}$ & OxA-2474 & 38500 & 1300 & 1300 & 0,12 \\
\hline 18b-lower & MP & 125 & charcoal & $14 \mathrm{C}$ & OxA-2475 & 40700 & 1600 & 1600 & 1,15 \\
\hline $18 b$ & MP & $123-127$ & charcoal & $14 C$ & weighted mean & 38679 & 744 & & \\
\hline $20 \mathrm{~b} 2$ & MP & 128 & charcoal & $14 \mathrm{C}$ & GifA-89144 & 39300 & 1900 & 1900 & 0,48 \\
\hline $20 \mathrm{~b} 2$ & MP & 129 & charcoal & $14 \mathrm{C}$ & GifA-92506 & 43300 & 2900 & 2900 & 0,85 \\
\hline $20 b 2$ & $M P$ & $128-129$ & charcoal & $14 C$ & weighted mean & 40501 & 1589 & & \\
\hline \multicolumn{10}{|c|}{ L'Arbreda (Serinyà, Girona, Spain) } \\
\hline BE 116 (level I) sq. E2 & MP & 154 & charcoal & $14 \mathrm{C}$ & AA-3777 & 34100 & 750 & 750 & \\
\hline BE 116 (level I) sq. E2 & MP & 155 & charcoal & $14 \mathrm{C}$ & AA-3776 & 39400 & 1400 & 1400 & 0,92 \\
\hline BE 116 (level I) sq. E2 & MP & 156 & charcoal & $14 \mathrm{C}$ & AA-3778 & 41400 & 1600 & 1600 & 0,24 \\
\hline BE 116 (level I) sq. E2 & MP & 153 & charcoal & $14 \mathrm{C}$ & OxA-3731 & 44560 & 2400 & 2400 & 1,39 \\
\hline BE 116 (level I) sq. E2 & $M P$ & $153+155-56$ & charcoal & $14 C$ & weighted mean & 40961 & 965 & & \\
\hline \multicolumn{10}{|c|}{ Gorham's Cave (Gibraltar) } \\
\hline context $24^{\star}$ & transitional & 239 & charcoal & $14 \mathrm{C}$ & OxA-7857 & 32280 & 420 & 420 & \\
\hline context $18^{\star \star}$ & transitional & 240 & charcoal & $14 \mathrm{C}$ & OxA-7791 & 42200 & 1100 & 1100 & \\
\hline
\end{tabular}

* = remnant combustion zone

charcoal

OxA-7791

$422001100 \quad 1100$

$\star \star *$ combustion zone

\section{C on CHARCOAL vs. $14 \mathrm{C}$ on BONE}

\begin{tabular}{|c|c|c|c|c|c|c|c|c|c|}
\hline \multicolumn{10}{|c|}{ Ermitons (Sales de Llierca, Girona, Spain) } \\
\hline IV & MP & 163 & bone & $14 \mathrm{C}$ & OxA-3725 & 33190 & 660 & 660 & \\
\hline IV & MP & 164 & charcoal & $14 \mathrm{C}$ & CSIC-197/IAB-3 & 36430 & 1800 & 1800 & \\
\hline \multicolumn{10}{|c|}{ L'Arbreda (Serinyà, Girona, Spain) } \\
\hline BE 116 & MP & 153 & bone & $14 \mathrm{C}$ & OxA-3731 & 44560 & 2400 & 2400 & \\
\hline BE 116 & MP & 154 & charcoal & $14 \mathrm{C}$ & AA-3777 & 34100 & 750 & 750 & \\
\hline $\mathrm{BE} 116$ & MP & 155 & charcoal & $14 \mathrm{C}$ & AA-3776 & 39400 & 1400 & 1400 & 0,49 \\
\hline BE 116 & MP & 156 & charcoal & $14 \mathrm{C}$ & AA-3778 & 41400 & 1600 & 1600 & 0,59 \\
\hline$B E 116$ & $M P$ & $155-156$ & charcoal & $14 C$ & weighted mean & 40267 & 1054 & & \\
\hline
\end{tabular}

\section{C on CHARCOAL vs. $14 \mathrm{C}$ on HUMUS}

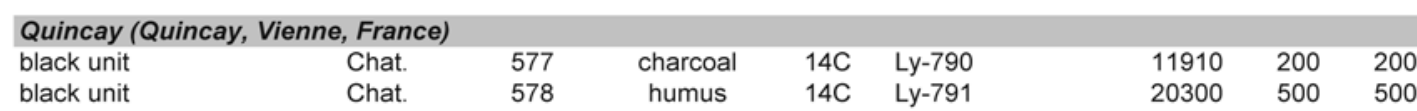

Tab 2. 
14C on CHARCOAL vs. $14 \mathrm{C}$ on UNKNOWN MATERIAL

$\begin{array}{llllllrrr}\text { Beneito (Muro, Alicante, Spain) } & & & & & & \\ \text { basal; X (D1) } & \text { MP } & 162 & ? & 14 C & ? & 30160 & 680 \\ \text { basal; X (D1) } & \text { MP } & 161 & \text { charcoal } & 14 C & \text { AA-1387 } & 38800 & 1900 & 1900\end{array}$

14C ON CHARCOAL VS. TL / OSL ON SEDIMENT / BURNT SILEX

\begin{tabular}{|c|c|c|c|c|c|c|c|c|c|}
\hline \multicolumn{10}{|c|}{ Tournal (Bize, Aude, France) } \\
\hline \multirow[t]{4}{*}{ C (Sq. K29) } & MP & 749 & charcoal & $14 C$ & Ly-1676 & 33600 & 1300 & 1300 & \\
\hline & MP & 744 & burnt silex? & TL? & Gif-? & 33000 & 4000 & 4000 & 0,00 \\
\hline & MP & 745 & burnt silex? & TL? & Gif-? & 33000 & 8000 & 8000 & 0,00 \\
\hline & $M P$ & 744-745 & burnt silex? & $T L ?$ & weighted mean & 33000 & 3578 & & \\
\hline \multicolumn{10}{|c|}{ Gorham's Cave (Gibraltar) } \\
\hline context 22/22D* & MP & 245 & sediment & OSL & MacGor-3 & 35000 & 7000 & 7000 & \\
\hline context $22 / 22 D^{\star}$ & MP & 244 & charcoal & $14 \mathrm{C}$ & OxA-6075 & 45300 & 1700 & 1700 & 0,59 \\
\hline context $22 / 22 D^{*}$ & MP & 246 & charcoal & $14 \mathrm{C}$ & OxA-7790 & 51700 & 3300 & 3300 & 1,39 \\
\hline $\begin{array}{l}\text { context } 22 / 22 D^{*} \\
{ }^{*}=\text { combustion zo }\end{array}$ & $M P$ & $244+246$ & charcoal & $14 C$ & weighted mean & 46642 & 1511 & & \\
\hline \multicolumn{10}{|c|}{ Brugas (Vallabrix, Gard, France) } \\
\hline 4 & MP & 679 & charcoal & $14 C$ & Ly-2351 & 29000 & 860 & 860 & \\
\hline 4 & MP & 678 & charcoal & $14 \mathrm{C}$ & Ly-2038 & $>32000$ & & & \\
\hline 4 & MP & 676 & burnt silex & TL & Gif-? & 58200 & 7500 & 7500 & 0,58 \\
\hline 4 & MP & 677 & burnt silex & TL & Gif-? & 65900 & 9900 & 9900 & 0,27 \\
\hline 4 & MP & 674 & burnt silex & TL & $?$ & 63000 & 5800 & 5800 & 0,01 \\
\hline 4 & MP & 675 & burnt silex & TL & Gif-? & 69000 & 10800 & 10800 & 0,55 \\
\hline 4 & MP & $674-677$ & burnt silex & $T L$ & weighted mean & 63063 & 3843 & & \\
\hline
\end{tabular}

\section{C on CHARCOAL vs. ESR}

\begin{tabular}{|c|c|c|c|c|c|c|c|c|c|}
\hline \multicolumn{10}{|c|}{ Castillo (Puente Viesgo, Cantabria, Spain) } \\
\hline $18 c$ & MP & 122 & bone & ESR & $?$ & 39900 & 4600 & 4600 & 0,28 \\
\hline $18 \mathrm{c}$ & MP & * & bone & ESR & ? & 40000 & 5000 & 5000 & 0,28 \\
\hline $18 c$ & $M P$ & $121-122+$ & bone & ESR & weighted mean & 38427 & 2610 & & \\
\hline $18 \mathrm{c}$ & MP & 120 & charcoal & $14 \mathrm{C}$ & GifA-89147 & 39500 & 2000 & 2000 & 0,36 \\
\hline $18 \mathrm{c}$ & MP & 119 & charcoal & $14 \mathrm{C}$ & OxA-2478 & 39800 & 1400 & 1400 & 0,29 \\
\hline $18 \mathrm{c}$ & MP & 116 & charcoal & $14 \mathrm{C}$ & AA-2405 & 40000 & 2100 & 2100 & 0,12 \\
\hline $18 \mathrm{c}$ & MP & 117 & charcoal & $14 \mathrm{C}$ & OxA-2476 & 40700 & 1500 & 1500 & 0,26 \\
\hline $18 \mathrm{c}$ & MP & 118 & charcoal & $14 \mathrm{C}$ & OxA-2477 & 41100 & 1700 & 1700 & 0,45 \\
\hline $18 \mathrm{c}$ & $M P$ & $116-120$ & charcoal & $14 \mathrm{C}$ & weighted mean & 40621 & 750 & & \\
\hline
\end{tabular}

${ }^{*}=$ Cabrera Valdés et al. 2001

\section{C ON CHARCOAL I CARBONACEOUS EARTH vS. U-SERIES}

$\begin{array}{lccc}\text { Columbeira (Bombarral, Portugal) } & & \\ 16=7 & \text { MP } & 57 & \text { cc/ce* }^{*} \\ 16=7 & \text { MP } & 58 & \text { tooth } \\ 16=7 & \text { MP } & 59 & \text { tooth } \\ 16=7 & M P & 58-59 & \text { tooth } \\ 20=8 & \text { MP } & 54 & \text { cc/ce* } \\ 20=8 & \text { MP } & 55 & \text { tooth } \\ 20=8 & \text { MP } & 56 & \text { tooth } \\ 20=8 & \text { MP } & 55-56 & \text { tooth }\end{array}$

${ }^{*}=$ charcoal/carbonaceous earth
14C Gif-2703**

U-series SMU-235E1

U-series SMU-238E1

$U$-series weighted mean

14C Gif-2704**

U-series SMU-236E1 $1^{\star \star \star}$

U-series SMU-236E1 ${ }^{* \star \star *}$

$U$-series weighted mean

** = inadequate dating material (Zilhao 2000) $* * *$ identical sample

$\begin{array}{rrrr}26400 & 750 & 750 & \\ 35876 & 27299 & 35583 & 0,34 \\ 54365 & 22240 & 27525 & 0,26 \\ 46990 & 17240 & & \\ 28900 & 950 & 950 & \\ 60927 & 27405 & 35522 & 0,39 \\ 101487 & 38406 & 55919 & 0,61 \\ 74620 & 22310 & & \end{array}$

\section{C ON BONE / TEETH vS. U-SERIES}

$\begin{array}{lccl}\text { Zafarraya (Alcaucin, Málaga, Spain) } & & \\ \text { I (3-7) } & \text { MP } & 167 & \text { tooth } \\ \text { I (3-7) } & \text { MP } & 168 & \text { tooth } \\ \text { I (3-7) } & \text { MP } & 169 & \text { tooth } \\ \text { I (3-7) } & \text { MP } & 170 & \text { tooth } \\ \text { I (3-7) } & \text { MP } & 168-170 & \text { tooth } \\ \text { I (8) } & \text { MP } & 172 & \text { tooth } \\ \text { I (8) } & \text { MP } & 171 & \text { tooth } \\ \text { D } & \text { MP } & 173 & \text { tooth }\end{array}$

$\begin{array}{clrrrr}\text { 14C } & \text { Gif-9140-II* } & 29800 & 600 & 600 & \\ \text { U-series } & \text { Gif-9140-II* } & 25100 & 1300 & 1300 & 0,55 \\ \text { U-series } & \text { Gif-9140-II* } & 26900 & 2700 & 2700 & 0,30 \\ \text { U-series } & \text { Gif-9140-II* } & 31700 & 3600 & 3600 & 1,50 \\ \text { U-series } & \text { weighted mean } & 26038 & 1114 & & \\ \text { U-series } & \text { Gif/LSM-9140-I* } & 31700 & 3600 & 3600 & \\ \text { 14C } & \text { Gif/LSM-9140-I* } & 31800 & 550 & 550 & \\ \text { U-series } & & 33400 & 2000 & 2000 & \end{array}$

Tab. 2 (Cont.). 


\section{C On BONE vS. ESR}

\begin{tabular}{|c|c|c|c|c|c|c|c|c|c|}
\hline \multicolumn{10}{|c|}{ Combe Sauniere (Sarliac-sur-I'Isle, Dordogne, France) } \\
\hline $\mathrm{x}$ & Chat. & 723 & tooth & ESR & ? & 36400 & 2500 & 2500 & \\
\hline $\mathrm{x}$ & Chat. & 722 & bone & $14 \mathrm{C}$ & OxA-6504 & 33000 & 900 & 900 & 2,30 \\
\hline $\mathrm{x}$ & Chat. & 720 & bone & $14 \mathrm{C}$ & OxA-6503 & 35900 & 1100 & 1100 & 0,36 \\
\hline $\mathrm{x}$ & Chat. & 721 & bone & $14 \mathrm{C}$ & OxA-6503* & 38100 & 1000 & 1000 & 2,30 \\
\hline$x$ & Chat. & $720-722$ & bone & $14 C$ & $\begin{array}{l}\text { weighted mean } \\
{ }^{\star}=\text { tripeptide }\end{array}$ & 35449 & 572 & & \\
\hline
\end{tabular}

14C on SHELL vs. U-series

\begin{tabular}{|c|c|c|c|c|c|c|c|c|c|}
\hline \multicolumn{10}{|c|}{ Figueira Brava (Sesimbra, Portugal) } \\
\hline $2 ?$ & MP? & 9 & shell & $14 C$ & ICEN-387 & 30930 & 700 & 700 & \\
\hline 2 & MP & 11 & tooth & U-series & SMU-232E1* & 30561 & 11759 & 10725 & 0,33 \\
\hline 2 & MP & 12 & tooth & U-series & SMU-232E2* & 44806 & 15889 & 13959 & 0,50 \\
\hline 2 & $M P$ & $11-12$ & tooth & U-series & $\begin{array}{l}\text { weighted mean } \\
{ }^{*}=\text { identical sample }\end{array}$ & 35600 & 9450 & & \\
\hline
\end{tabular}

TL / OSL

Conceicao (Alcochete, Portugal)

C-topo

$\mathrm{MP}^{*}$

* $=$ MP lies in layer $D$ below $C$

\begin{tabular}{|c|c|c|c|c|c|c|c|c|c|}
\hline \multicolumn{10}{|c|}{ Roche a Pierrot (Saint-Cesaire, Charente-Maritime, France) } \\
\hline 10 & MP & 390 & ? & TL & ? & 40900 & 2500 & 2500 & 0,20 \\
\hline 11 & MP & 391 & ? & TL & ? & 38200 & 3300 & 3300 & 0,55 \\
\hline \multirow[t]{2}{*}{12} & MP & 392 & ? & $T L$ & ? & 42400 & 4800 & 4800 & 0,41 \\
\hline & $M P$ & $390-392$ & ? & $T L$ & weighted mean & 40281 & 1840 & & \\
\hline \multicolumn{10}{|c|}{ Carigüela (Pinar, Granada, Spain) } \\
\hline & MP & 189 & silex & TL & TB-2 & \multicolumn{4}{|l|}{28000} \\
\hline & MP & 187 & silex & TL & TB-5 & \multicolumn{4}{|c|}{$31000-35000$} \\
\hline & MP & 188 & silex & TL & TB-1 & \multicolumn{4}{|l|}{32000} \\
\hline & MP & 186 & silex & TL & TB-12 & \multicolumn{4}{|l|}{39000} \\
\hline & MP & 185 & silex & TL & TB-3 & \multicolumn{4}{|l|}{46000} \\
\hline & MP & 184 & silex & TL & TB-9a & \multicolumn{4}{|l|}{48000} \\
\hline
\end{tabular}

TL vs. ESR

Le Moustier (Le Moustier, Dordogne, France)

।

K-I

$\begin{array}{cc}\text { MP/Chat.? } & 801 \\ \text { MP } & 800 \\ \text { MP } & 799 \\ \text { MP } & 799-801 \\ \text { MP } & 798 \\ \text { MP } & 797 \\ \text { MP } & 797-798 \\ \text { MP } & 796\end{array}$

burnt silex

burnt silex

burnt silex

burnt silex

$\mathrm{H}[2 \mathrm{a}-7 \mathrm{c}]$

$\mathrm{H}[2 \mathrm{a}-7 \mathrm{c}]$

$H[2 a-7 c]$

$\mathrm{H} 2-\mathrm{H} 9$

MP $\quad 796$

tooth

tooth

tooth

burnt silex

$T L \quad T B-9 a$

48000

El Pendo (Escobedo de Camargo, Cantabria, Spain)

\begin{tabular}{|c|c|c|c|c|c|c|c|c|}
\hline 26 & MP & * & & ESR & $?$ & 33700 & 1300 & 1300 \\
\hline 28 & MP & * & & ESR & $?$ & 14300 & 300 & 300 \\
\hline $32(H)$ & MP & * & & ESR & $?$ & 30500 & 300 & 300 \\
\hline B & MP & $* *$ & & ESR & $?$ & $<40000$ & & \\
\hline D & MP & $* *$ & burnt silex? & TL & $?$ & 83790 & 8291 & 8291 \\
\hline $\mathrm{F}$ & MP & $* *$ & burnt silex? & $\mathrm{TL}$ & $?$ & 39626 & 3864 & 3864 \\
\hline
\end{tabular}

* = Montes Barquín and Sanguino González 2001; ${ }^{\star \star}=$ Montes Barquín 2000

\section{U-SERIES}

Gruta do Escoural (Évora, Montemor-o-Novo, Portugal)

test 3a (90-100)

test $3 a(80-90)$

test $3 a(60-70)$

test $3 a$

$\begin{array}{lcl}\text { MP } & 33 & \text { tooth } \\ \text { MP } & 34 & \text { tooth } \\ \text { MP } & 35 & \text { tooth } \\ \text { MP } & 33-35 & \text { tooth }\end{array}$

Foz do Enxarrique (Ródao, Portugal)

$\begin{array}{lccc}\mathrm{C} & \text { MP } & 6 & \text { tooth } \\ \mathrm{C} & \mathrm{MP} & 7 & \text { tooth } \\ \mathrm{C} & \mathrm{MP} & 8 & \text { tooth } \\ \mathrm{C} & \mathrm{MP} & 6-8 & \text { tooth }\end{array}$

Tab. 2 (Cont.).

$\begin{array}{llrrrr}\text { U-series } & \text { SMU-248* } & 26400 & 5800 & 5500 & 1,33 \\ \text { U-series } & \text { SMU-249*} & 39800 & 10000 & 9000 & 0,61 \\ \text { U-series } & \text { SMU-250 } & 48900 & 11000 & 10000 & 0,98\end{array}$

$U$-series weighted mean $33070 \quad 4560$

* $=$ low U content (Zilhao 2000)

$\begin{array}{llrrrr}\text { U-series } & \text { SMU-225 } & 32938 & 1055 & 1055 & 0,74 \\ \text { U-series } & \text { SMU-226 } & 34088 & 800 & 800 & 0,29 \\ \text { U-series } & \text { SMU-224 } & 34093 & 920 & 920 & 0,27 \\ \text { U-series } & \text { weighted mean } & 33806 & 524 & & \end{array}$




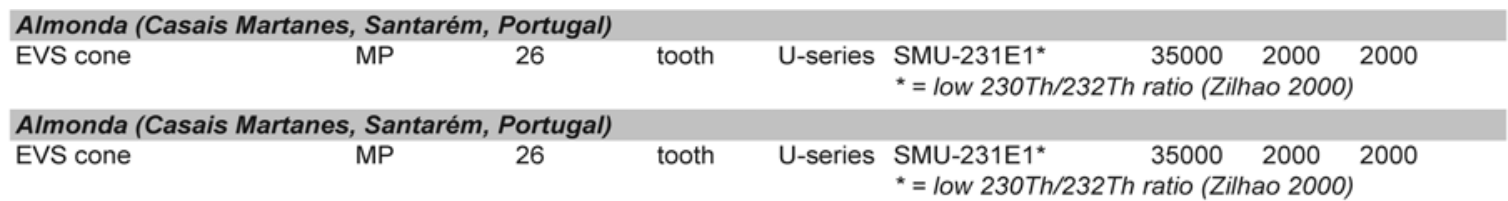

\section{U-SERIES vS. ESR}

\begin{tabular}{|c|c|c|c|c|c|c|c|c|c|}
\hline \multicolumn{10}{|c|}{ Bajondillo (Torremolinos, Málaga, Spain) } \\
\hline basal level & MP & 226 & travertine & ESR: EU & & 25300 & 2530 & 2530 & 0,48 \\
\hline basal level & MP & 227 & travertine & ESR: LU & & 26500 & 3975 & 3975 & 0,04 \\
\hline basal level & MP & 228 & travertine & U-series & & 27300 & 1700 & 1700 & 0,30 \\
\hline basal level & $M P$ & $226-228$ & & all & weighted mean & 26658 & 1330 & & \\
\hline
\end{tabular}

Tab. 2 (Cont.). Radiometric dates for the SW European Middle Palaeolithic excluding radicarbon measurements on bone samples. WD - No. in William Davies datelist (see annotation 1); MAT. - material dated; METH. - dating method; STD standard deviation; $t$-val. - t-value. MP - Middle Palaeolithic; Chat. - Châtelperronian.

to be regarded "highly questionable and/or irrelevant" in contribution to the issue discussed (Pettitt and Pike 2001: 416). A 'transitional industry' from Gorham's Cave may be due to stratigraphic palimpsests, since both radiocarbon measurements obtained on charcoal diverge by some $10,000{ }^{14} \mathrm{C} \mathrm{BP}$ (OxA-7857 for context 24: 32,280 $\pm 420{ }^{14} \mathrm{C} \mathrm{BP} v s$. OxA-7791 for context 18: $42,000 \pm 1100{ }^{14} \mathrm{C} \mathrm{BP}$ ). Stratigraphical inversion of layers most plausibly account for the El Pendo series (Montes Barquín 2000; Montes Barquín and Sanguino González 2001).

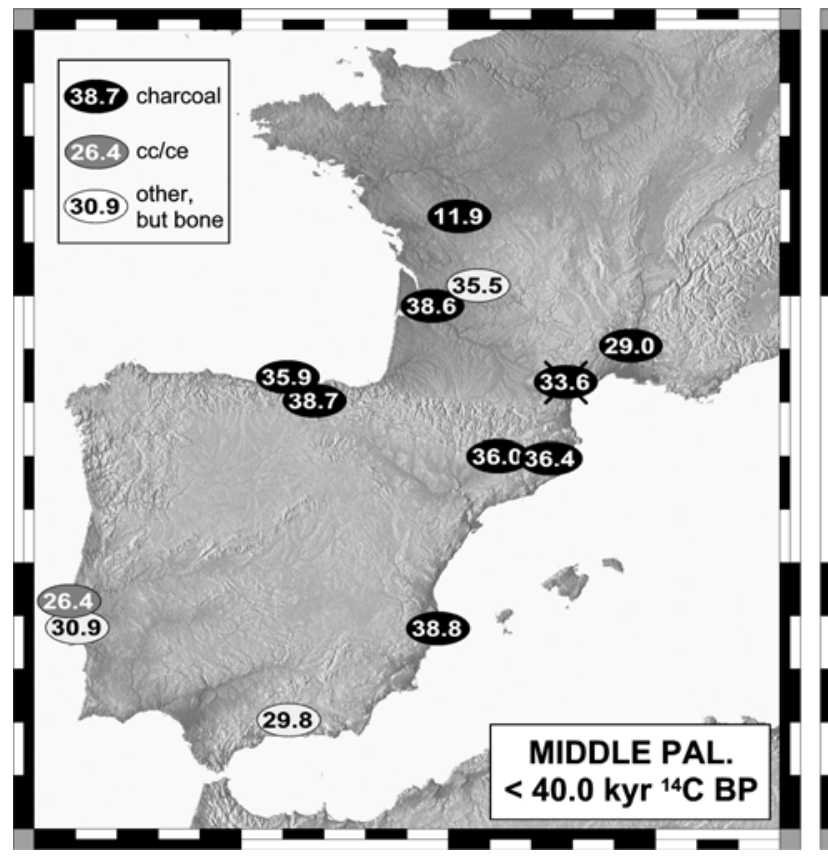

Fig. 11. Radiometric dates ('last appearance data': LAD's) for the SW European Middle Palaeolithic, with radiocarbon measurements (left) sorted for material dated and given in $\mathrm{kyr}{ }^{14} \mathrm{C} \mathrm{BP}$, when required as weighted means, and non-radiometric measurements (right) sorted for method of dating and given in kyr BP, when required as weighted means.
At Brugas and Columbeira non-radiocarbon age-determinations all dating older than $45.0 \mathrm{kyr}$ ago have produced results significantly older than radiocarbon measurements. In contrast, two radiocarbon measurements on charcoal at Gorham's Cave (context 22/22D) are much older than the OSL-dated sediment. At Figueira Brava a radiocarbon measurement on a Patella sp. shell has been dated to $30,930 \pm 700{ }^{14} \mathrm{C}$ BP (ICEN-387). Although Zilhão (2000) attributes the date to the LMP level 2, its precise stratigraphic proveniance remains unclear. Two U-series measurements of the

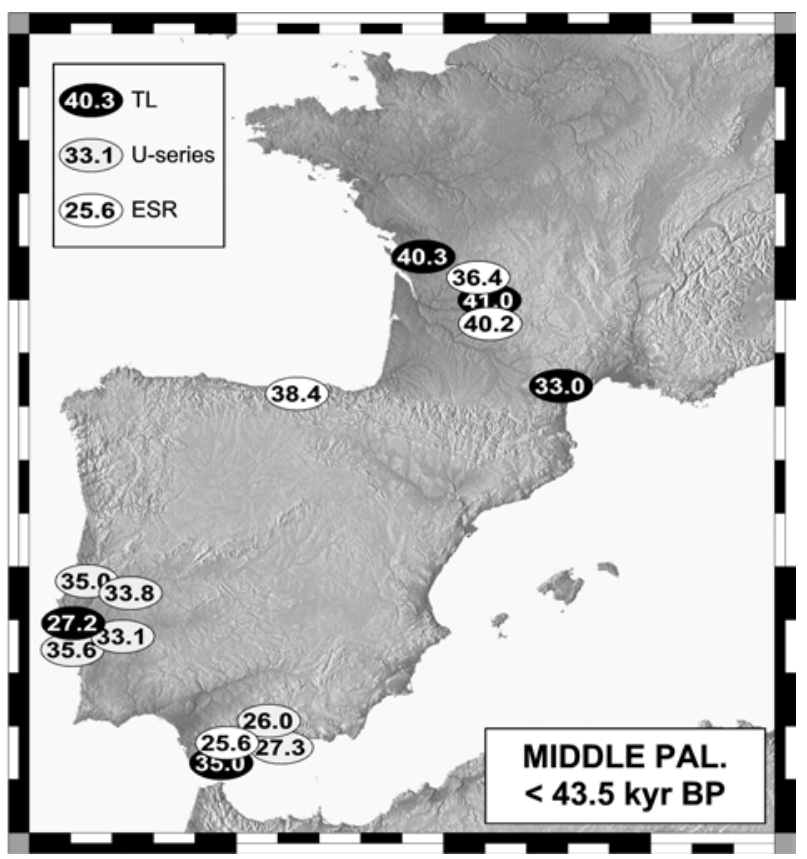


same sample gave strongly divergent results with extremely high standard deviations. Whereas the younger date was given as $30.6 \pm 11.8 \mathrm{kyr} \mathrm{BP}$ (SMU-232E1), the older one resulted in $44.8 \pm 15.9$ kyr BP (SMU-232E2).

For the period under discussion in general, nonradiocarbon methods of dating have to be regarded as less reliable due to the often extremely high standard deviations, when compared with ${ }^{14} \mathrm{C}$ (e.g. Schwarcz 2001). Even in cases where radiocarbon measurements appear in agreement with results obtained from the various non-radiocarbon dating techniques, this may be simply coincidental (10).

The LMP from Tournal $\mathrm{C}$ is dated to $33,600 \pm$ $1300{ }^{14} \mathrm{C} \mathrm{BP}$ (Ly-1667) by radiocarbon and to 33.0 $\pm 3.6 \mathrm{kyr}$ BP by TL on burnt silex (WM of two dates), whereas a sample from the overlaying $\mathrm{Au}-$ rignacian of level $\mathrm{G}$ is older than $35,800{ }^{14} \mathrm{C} \mathrm{BP}$ (Ly1898; Tavoso 1976; cf. Tab. 1). The Châtelperronian of Combe Sauniere has been dated by ESR (36.4 \pm 2.5 kyr BP; Tab. 2) as well as by radiocarbon on two bone samples. Although the WM of the radiocarbon measurements $\left(35,449 \pm 572{ }^{14} \mathrm{C} \mathrm{BP}\right)$ is largely in agreement with the date produced by ESR, the individual measurements are strongly divergent. Moreover, OxA-6503 gave a date of $35,900 \pm 1100{ }^{14} \mathrm{C} \mathrm{BP}$, whereas a tripeptide-measurement of the same sample resulted in 38,100 \pm $1000{ }^{14} \mathrm{C} \mathrm{BP}$, close to the date that we propose for the earliest Aurignacian in the North of the Iberian Peninsula (L'Arbreda; cf. Fig. 10).

Non-radiocarbon dates younger than $30.0 \mathrm{kyr}$ BP have been obtained from Bajondillo (ESR and U-series) with a WM of $26.7 \pm 1.3 \mathrm{kyr} \mathrm{BP}$ and from Conceicão (TL), for a level overlaying the LMP (QTSL-CNC-11: 27.2 $\pm 2.5 \mathrm{kyr}$ BP). TL-dates from Roche à Pierrot (St. Césaire) and Carigüela - although rather heterogeneous - indicate that LMP layers are older than $40.0 \mathrm{kyr}$ BP. The same accounts for the TL and ESR-measurements obtained from the Le Moustier sequence.

A low ${ }^{230} \mathrm{Th} /{ }^{232} \mathrm{Th}$-ratio explains the relatively young age for the MP finds from the EVS-cone at Almonda (Zilhão 2000b), and low U-contents for the samples SMU-248 and SMU-249 at Gruta do Escoural (Zilhão 2000b) point to the higher reliabi-

(10) Strikingly, at some sites radiocarbon measurements and non-radiocarbon methods have produced identical ages - at least within the errors contained in the standard deviations (e.g. Combe Sauniere, Zafarraya). This is the more surprising, since the calibration records that are available today, imply that radiocarbon age-determinations underestimate the calendric scale for several thousand BP within the time-period under discussion. lity of the SMU-250-sample, giving an age of 48.9 $\pm 11.0 \mathrm{kyr}$ BP.

The only consistent series of U/Th-measurements comes from Foz do Enxarrique $\mathrm{C}$ with an WM of $33.8 \pm 0.5 \mathrm{kyr}$ BP. Unfortunately the relation between LMP lithic artefacts and the faunal material dated at this site remains unclear (cf. Zilhão 1997).

\section{CONCLUSIONS AND DISCUSSION}

Our analyses of the radiometric evidence for the MP/UP transition in SW Europe has augmented a range of criteria for quality control in data mining as well as in terms of advanced numeric data processing. The results emphasize sample material, problems of possible adhering contamination, and on measuring precision. Comparisions of bone and charcoal radiocarbon dates points to extreme discrepancies between these sample categories, with bone dates being systematically too young (Jöris et al. 2001; cf. Fig. 4-5). These findings do not refute the reliability of radiocarbon measurements of bone in general, but call for circumspection in evaluation of quality and reliability of such dates. Against this background, bone dates may contribute less than initially hoped to the understanding of the chronological issues surrounding the transition from the LMP to the EUP in Europe, and in particular we must remain cautious when interpreting ${ }^{14} \mathrm{C}$-bone data close to the detection limits of the radiocarbon method (Fig. 3).

\subsection{On the age of the MP/UP transition in SW Europe}

Evaluation of LMP radiometric dates from $\mathrm{SW}$ Europe $<40,000{ }^{14} \mathrm{C} \mathrm{BP}$ and $<43.5 \mathrm{kyr}$ non $-{ }^{14} \mathrm{C} \mathrm{BP}$ (Tab. 2; Fig. 11) has shown that minimal reliability - if any - is given for dates younger than 38,300 ${ }^{14} \mathrm{C}$ BP. Based on radiocarbon dates obtained on charcoal, SW European LMP LAD's range between 35,900 ${ }^{14} \mathrm{C}$ BP (Morín, level 10: SI-951-A) and $38,800{ }^{14} \mathrm{C} \mathrm{BP}$ (Beneito: AA-1387), with a WM of Beneito-, Castillo- (level 18b), Barbas-, Ermitons-, Fuentes de San Cristobal- and Morín-LAD's of 38,391 $\pm 381{ }^{14} \mathrm{C} \mathrm{BP}$ (Fig. 11, left). This SW European LMP LAD is statistically identical with the FAD of the archaic Aurignacian at L'Arbreda (WM: 38,307 $\pm 552{ }^{14} \mathrm{C} \mathrm{BP}$ ) and is in overall agree- 


\begin{tabular}{|l|ll|ll|ll|l|}
\hline 14C-Age [BP] & \multicolumn{2}{|c|}{ Cal Age [cal BC] 68\% (95\%) } & \multicolumn{2}{|c|}{ Cal Age [cal BP] 68\% (95\%) } & Notes \\
\hline $40000 \pm 800$ & $40550 \pm 430$ & $(41410-39690)$ & $42500 \pm 430$ & $(43360-41640)$ & $(1)$ \\
$38300 \pm 766$ & $39890 \pm 290$ & $(40470-39310)$ & $41840 \pm 290$ & $(42420-41260)$ & $(2)$ \\
$36500 \pm 730$ & $38610 \pm 940$ & $(40490-36730)$ & $40560 \pm 940$ & $(42440-38680)$ & $(3)$ \\
$35400 \pm 708$ & $37950 \pm 1080$ & $(40110-35790)$ & $39900 \pm 1080$ & $(42060-37740)$ & $(4)$ \\
$33500 \pm 670$ & $36360 \pm 1710$ & $(39780-32940)$ & $38310 \pm 1710$ & $(41730-34890)$ & $(5)$ \\
$30000 \pm 600$ & $31900 \pm 700$ & $(33300-30500)$ & $33850 \pm 700$ & $(35250-32450)$ & $(1)$ \\
$28000 \pm 560$ & $30190 \pm 690$ & $(31570-28810)$ & $32140 \pm 690$ & $(33520-30760)$ & $(6)$ \\
\hline
\end{tabular}

(1) commonly accepted limits of the MP/UP transition

(2) FAD for the Aurignacian in SW Europe, this work

(3) FAD for the Aurignacian in SW Europe after Zilhão and d'Errico (1999)

(4) FAD for the Aurignacian in France, this work

(5) FAD for the Aurignacian in the SW of the Iberian Peninsula after Vega Toscano (1990) and Zilhão (1993)

(6) average of youngest dates for the European MP after various authors

(e.g.: Bocquet-Appel and Demars 2000; Zilhão 1993; cf. Hublin et al. 1995)

Tab 3. Calibration of seven fictive radiocarbon measurements [BP] spanning around the Middle to Upper Palaeolithic (MP/ UP) transition with typical errors in the range of $2 \%$ of total radiocarbon BP. Calibration was established using the CALPAL-2003 data set (see annotation 8). FAD - First appearance data.

ment with LMP LAD's available for other parts of Europe (Fig. 6), implying a sudden and simultaneous ending of the MP all over Europe.

To summarize, we note

- that the LMP discontinues over the whole of SW Europe at ca. $38,300{ }^{14} \mathrm{C} \mathrm{BP}$,

- at a time for which similar LMP LAD's and Aurignacian FAD's can be fixed in various parts of Europe (Fig. 6).

In terms of calibrated radiocarbon- 'years' this transition falls into the shift from the interstadial conditions of GI 11 (GI = Greenland interstadial) to the stadial ones of GS 11 (GS = Greenland stadial) at around $39.9 \mathrm{kyr}$ cal BC (Fig. 8; cf. Tab. 3) (11).

We can therefore confirm the high antiquity of the oldest Aurignacian in the North of the Iberian Pensinsula, i.e. Cantabria and Catalunya, but - in contrast to the radiocarbon record - evidence from the non-radiocarbon methods of dating for the LMP (Tab. 2; Fig. 11, bottom) does not withstand criticism and the data available are too weak to prove LMP persistence in the southern half of the Iberian Peninsula until 33,500 ${ }^{14} \mathrm{C} \mathrm{BP}$ or later, at least not until the Aurignacian of Gato Preto.

(11) Whereas our FAD's for the Aurignacian of SW Europe preceded those proposed by Zilhão and d'Errico (1999) by some $1800{ }^{14} \mathrm{C} \mathrm{BP}$, in calibrated terms FAD-differences would be in the range of only $1.3 \mathrm{kyr}$ cal, still placing the transition into GS 11 .
Although the available radiometric dates represent regionally different patterns of hominid presence, we cannot confirm the existance of an "Ebro Frontier", that geographically distinguishes between Aurignacian industries to the NE and LMP ones in the SW against the background of these data. Rather our data implies that the southern part of the Iberian Peninsula was already void of MP hominids long before the appearance of the first Aurignacians.

\subsection{Climate controlled population dynamics?}

Based on radiocarbon evidence, the oldest Aurignacian sites of SW Europe cluster in the North of the Iberian Peninsula (Fig. 12: A; cf. Fig. 9), while the southern French Aurignacian does not date to before $35,400{ }^{14} \mathrm{C}$ BP and Aurignacian sites from the southern part of the Iberian Peninsular do not pre-date 33,500 ${ }^{14} \mathrm{C} \mathrm{BP}$ (Vega Toscano 1990; Zilhão 1993). This pattern may best be explained by a northward spread (Fig. 12: B) of Aurignacian populations in a severe cold phase (GS $9=$ Heinrichevent 4: H4; Fig. 8) shortly after GS 11 . In a recent study F. d'Errico and M. F. Sánchez Goñi (2003) have characterized the highly arid desert-steppelike H4-environments found over large areas of the Iberian Peninsula as inhospitable: conditions that 


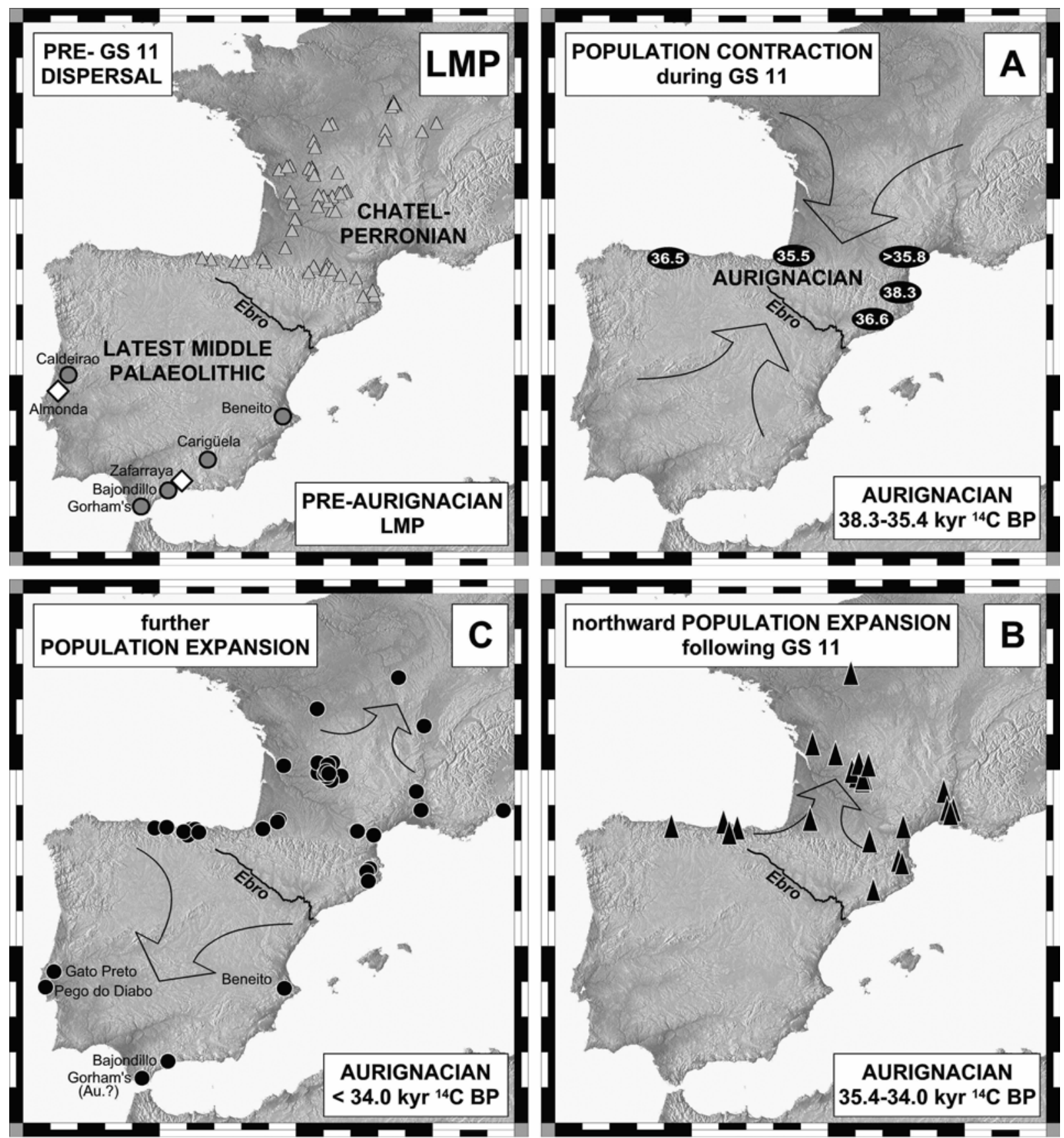

Fig. 12. Model of regional population shifts (arrows) around the transition from the Latest Middle Palaeolithic (LMP) to the Aurignacian in SW Europe (clockwise: LMP-A-B-C; cf. Fig. 8), covering the time span of ca. 42,000-28,000 ${ }^{14} \mathrm{C} \mathrm{BP}$ over a period of strong climatic fluctuations during the last interpleniglacial (OIS 3; cf. Fig. 2, 7-8).

GS - Greenland stadial.

may have triggered a northward shift of populations (Fig. 8, 12: B), followed by a further expansion into the NE as well as into the SW at the onset of GI 8 (Fig. 12: C).

\subsection{Makers of the Aurignacian}

Based on the chronometric dates that cover the European MP/UP transition there is neither radio- 
metric nor stratigraphic indication for incoming populations that may have colonized Europe from East to West (12), nor is there reliable proof for a late persistence of LMP younger than $38,300{ }^{14} \mathrm{C}$ BP. Against these data, the geographical pattern of both LMP LAD's and Aurignacian FAD's (i.e. the MP/ UP transition) can be best explained by a contraction of regional population dispersal into glacial refugia during GS 11. Such an interpretation would imply local in situ developments (13) of Aurignacian industries simultaneously in two different areas of Europe, separating the SW European Aurignacian without leaf-points from that of south-central and southeastern European sites which are characterized by the addition of a few of these artefact types. Consequently, this would imply that Neanderthals did indeed produce at least the earliest Aurignacian industries (cf. Churchill and Smith 2000).

Since the hominid fossil evidence is sparse and not entirely unambiguous during the Aurignacian, it would appear that unambiguous evidence of anatomically modern humans is not known prior to the European Middle UP.

\section{ACKNOWLEDGEMENTS}

We thank V. Cabrera Valdés and A. F. Bernaldo de Quirós for permission to study the bone industry from the new excavations at El Castillo. We kindly acknowledge F. d'Errico, A. J. M. Maíllo Fernández, I. Castanedo Tapia, M. Street, St. Wenzel and J. Zilhão for fruitful discussions and contributions to this paper. Furthermore we thank F. d'Errico and W. Davies for suppling literature and data prior to publication. N. Barton, O. Bar-Yosef, C. Gamble, Chr. Stringer and - especially - E. Turner we thank for valuable comments on an earlier draft of this article.

\section{BIBLIOGRAPHY}

ALLSWORTH-JONES, Ph. 1986: The Szeletian and the Transition from Middle to Upper Palaeolithic in Central Europe. Clarendon Press, Oxford.

(12) An infinite radiocarbon date $\left(>35,000{ }^{14} \mathrm{C} \mathrm{BP}\right)$ obtained from a newly discovered human mandible from Romania (Gibbons 2003: 894) does not prove the presence of Aurignacian early modern humans in Europe. Since the new fossil displays both anatomically modern human and archaic features one has to await further results from palaeoanthropology as well as new datations.

(13) Although such in situ development cannot be proven by the LMP industry of El Castillo 18 that Cabrera Valdés et al. (2001) attribute to an Aurignacian with archaic elements.
ASMUS, G. 1964: "Kritische Bemerkungen und neue Gesichtspunkte zur jungpaläolitischen Bestattung von Combe Capelle, Périgord". Eiszeitalter und Gegenwart 15: 181-6.

BECK, J. W.; RICHARDS, D. A.; EDWARDS, R. L.; SILVERMAN, B. W.; SMART, P. L.; DONAHUE, D. J.; HERERRA-OSTERHELD, S.; BURR, G. S.; CALSOYAS; L.; JULL, A. J. T. and BIDDULPH, D. 2001: "Extremely Large Variations of Atmospheric ${ }^{14} \mathrm{C}$ Concentration During the Last Glacial Period". Science 292: 2453-8.

BISCHOFF, J. L., LUDWIG, K., GARCÍA, J. F., CARBONELL, E., VAQUERO, M., STAFFORD, TH. W. and JULL, A. J. T. 1994: "Dating of the Basal Aurignacian Sandwich at Abric Romaní (Catalunya, Spain) by Radiocarbon and Uranium-Series". Journal of Archaeological Science 21 (4): 541-51.

BISCHOFF, J. L., SOLER, N., MAROTO, J. and JULIA, R. 1989: "Abrupt Mousterian/Aurignacian Boundary at c. 40 ka bp: Accelerator ${ }^{14} \mathrm{C}$ Dates from l'Arbreda Cave (Catalunya, Spain)". Journal of Archaeological Science 16: 563-76.

BLASCO SÁNCHEZ, M. F. and MONTES RAMÍREZ, L. 1997: "Los helénidos del yacimiento musteriense de Gabasa 1". BOLSKAN 14: 9-27.

BODU, P. 1990: "L'aplication de la méthode des remontages à l'étude du matériel lithique des premiers niveaux châtelperroniens de la Grotte du Renne á Arcysur-Cure (Yonne) ". In C. Farizy (dir.): Paléolithique moyen recent et Paléolithique supérieur ancien en Europe. Ruptures et transitions: examen critique des documents archéologiques. Actes du Colloque international de Nemours (9-11 Mai 1988). Mémoires du Musée de Préhistoire d’Ile de France 3. Nemours: 30912.

BOLUS, M. and RÜCK, O. 2000: "Eine Blattspitze aus Wittislingen, Lkr. Dillingen a. d. Donau (Bayern). Zur südwestlichen Verbreitungsgrenze spätmittelpaläolithischer Blattspitzeninventare". Archäologisches Korrespondenzblatt 30: 165-72.

BOQUET-APPEL, J.-P. and DEMARS, P. Y. 2000: "Neanderthal Contraction and Modern Human Colonization of Europe". Antiquity 74: 544-52.

BORDES, J. G. 1998: L'Aurignacian 0 en Périgord: analyse des données. Un exemple d'application d'une méthode de quantification des remontages d'intérêt stratigraphique: Caminade Est, couche G. Diplôme d'Etudes Approfondies. Universite Bordeaux I (manuscrit).

BOSINSKI, G. 1987: "Die große Zeit der Eiszeitjäger. Europa zwischen 40.000 und 10.000 v. Chr.". Jahrbuch des Römisch-Germanischen Zentralmuseums Mainz 34 (1): 3-139.

- 1990: Homo Sapiens. L'histoire des chasseurs du Paléolithique supérieur en Europe (40.000-10.000 av. J.C.). Errance. Paris.

CABRERA VALDÉS, V. 1984: El yacimento de la cueva 
de "El Castillo". Puente Viesgo, Santander. Bibliotheca Praehistorica Hispana XXII. C.S.I.C. Madrid.

CABRERA VALDÉS, V. and BISCHOFF, J. L. 1989: "Accelerator C-14 Dates for Early Upper Paleolithic (Basal Aurignacian) at El Castillo Cave (Spain)". Journal of Archaeological Science 16: 577-84.

CABRERA VALDÉS, V., MAÍLLO FERNÁNDEZ, J. M., LLORET, M. and BERNALDO DE QUIRÓS, F. 2001: "La transition vers le Paléolithique supérieur dans la grotte du Castillo (Cantabrie, Espagne): la couche 18". L'Anthropologie 105 (4): 505-32.

CABRERA VALDÉS, V., PIKE-TAY, A., LLORET, M. and BERNALDO DE QUIRÓS, F. 2000: "Continuity Patterns in the Middle-Upper Palaeolithic Transition on Cantabrian Spain". In C. B. Stringer, R. N. E. Barton and J. C. Finlayson (eds.): Neanderthals on the Edge. Papers from a Conference Marking the $150^{\text {th }}$ Anniversary of the Forbes' Quarry Discovery. Oxbow Books. Gibraltar: 85-93.

CABRERA VALDÉS, V., VALLADAS, H., BERNALDO DE QUIRÓS, F. and HOYOS, M. 1996: "La transition Paléolithique moyen-Paléolithique supérieur à El Castillo (Cantabrie): Nouvelles datations per le carbone14". Comptes-Rendus de l'Académie des Sciences de Paris 322 (2): 1093-8.

CANAL I ROQUET, J. and CARBONELL I ROURA, R. 1989: Catalunya paleolítica. Patronat Francesc Eiximenis. Girona.

CARBONELL, E.; GIRALT, S. and VAQUERO, M. 1994: "Abric Romaní (Capellades, Barcelone, Espagne): une importante séquence anthropisée au Pléistocène supérieur". Bulletin de la Société Préhistorique Française 91 (1): 47-55.

CARBONELL, E., M. VAQUERO, J. MAROTO, J., J. M. RANDO and MALLOL, C. 2000: "A Geographic Perspective on the Middle to Upper Palaeolithic Transition in the Iberian Peninsula". In O. Bar-Yosef and D. Pilbeam (eds.): The Geography of Neandertals and Modern Humans in Europe and the Greater Mediterranean. Peabody Museum of Archaeology and Ethnology. Harvard University. Cambridge: 5-34.

CHURCHILL, S. E. and SMITH, Fr. H. 2000: "Markers of the Early Aurignacian of Europe". Yearbook of Physical Anthropology 43: 61-115.

CLARK, J. D.; BEYENE, Y.; WOLDEGABRIEL, G.; HART, W. K.; RENNE, P. R.; GILBERT, H.; DEFLEUR, A.; SUWA, G.; KATOH, S.; LUDWIG, K.; BOISSERIE, J.- R.; ASFAW, B. and WHITE, T. D. 2003: "Stratigraphic, Chronological and Behavioural Contexts of Pleistocene Homo sapiens from Middle Awash, Ethiopia". Science 423: 747-52.

CONARD, N. J. and BOLUS, M. 2003: "Radiocarbon Dating the Appearance of Modern Humans and Timing of Cultural Innovations in Europe: New Results and New Challenges". Journal of Human Evolution 44: 331-71. DAVIES, W. 2001: “A Very Model of a Modern Human
Industry: New Perspectives on the Origins and Spread of the Aurignacian in Europe". Proceedings of the Prehistoric Society 67: 195-217.

DEMARS, P.Y. 1996: "La place du Piage et de Roc-deCombe (Lot) dans la transition du Paleolithique moyen au Paléolithique supérieur". Bulletin. Préhistorique du Sud-Ouest, Nouvelles Études 3: 11-35.

d'ERRICO, F. and SÁNCHEZ GOÑI, M. F. 2003: "Neandertal Extinction and the Millennial Scale Climatic Variability of OIS 3". Quaternary Science Reviews (e.p.).

d'ERRICO, F.; ZILHÃO, J.; BAFFIER, D.; JULIEN, M. and PELEGRIN, J. 1998: "Neanderthal Acculturation in Western Europe? A Critical Review of the Evidence and its Interpretation". Current Anthropology 39. Supplement, S-1-S44.

DJINDJIAN, F. 1999: "Datations ${ }^{14} \mathrm{C}$ du Paléolithique supérieur européen. Bilan et perspectives". In J. Evin, J., C. Oberlin, J. P. Daugas and J. F. Salles (eds.): Actes du 3ème Congr. Int. "Archéologie et ${ }^{14} C^{\prime}$ ”: Rev. d'Archéometrie Suppl. 1999 et Soc. Préhist. Franç. Mémoire 26. Lyon: 171-9.

DJINDJIAN, F.; KOZLOWSKI, J. and OTTE, M. 1999: "Le paléolithique supérieur en Europe". Armand Colin. Paris 1999.

FEDELE, F. G.; GIACCIO, B.; ISAIA, R. and ORSI, G. 2002: "Ecosystem Impact of the Campagnian Ignimbrite Eruption in Late Pleistocene Europe". Quaternary Research 57: 420-4.

GAMBIER, D. 1997: "Modern Humans at the Beginning of the Upper Palaeolithic in France". In G. A. Clark and C. M. Willwermet (eds.): Conceptual Issues in Modern Human Origins Research. Aldine de Gruyter: 117-131.

GEYH, M. R. 1969: "Versuch einer chronologischen Gliederung des marinen Holozän an der Nordseeküste mit Hilfe der statistischen Auswertung von ${ }^{14} \mathrm{C}$-Daten". Zeitschrift der Deutschen Geologischen Gesellschaft 188: 351-60.

GIBBONS, A. 2003: "Meeting: Physical Anthropology and Palaeoanthropology". Science 300: 893-4.

GILLESPIE, R. 1997: "Burnt and Unburnt Carbon: Dating Charcoal and Burnt Bone from the Willandra Lakes, Australia". Radiocarbon 39 (3): 239-50.

GIOIA, P. 1990: "An aspect of the transition between Middle and Upper Palaeolithic in Italy: the Uluzzian". In: C. Farizy (dir.): Paléolithique moyen recent et $\mathrm{Pa}$ léolithique supérieur ancien en Europe. Ruptures et transitions: examen critique des documents archéologiques. Actes du Colloque international de Nemours (911 Mai 1988). Mémoires du Musée de Préhistoire d'Ile de France 3. Nemours: 241-50.

GOUEDO, J.-M. 1990: "Les technologies lithiques du Châtelperronien de la couche X de la grotte du Renne d'Arcy-sur-Cure (Yonne)". In C. Farizy (dir.): Paléolithique moyen recent et Paléolithique supérieur ancien en Europe. Ruptures et transitions: examen critique des 
documents archéologiques. Actes du Colloque international de Nemours (9-11 Mai 1988). Mémoires du Musée de Préhistoire d'Ile de France 3. Nemours: 305-8.

GROOTES, P. M. 1977: Thermal Diffusion Isotopic Enrichment and Radiocarbon Dating Beyond 50.000 Years BP. Groningen.

HEDGES, R. and PETTITT, P. 1999: "On the Validity of Archaeological Radiocarbon Dates beyond 30,000 Years BP'. In J. Evin, J., C. Oberlin, J. P. Daugas and J. F. Salles (eds.): Actes du 3ème Congr. Int. "Archéologie et ${ }^{14} C^{\prime}$ ": Rev. d'Archéometrie Suppl. 1999 et Soc. Préhist. Franc. Mémoire 26. Lyon: 137-41.

HENRY-GAMBIER, D. 2002 : "Les fossiles de Cro-Magnon (Les Eyzies-de-Tayac, Dordogne): Nouvelles données sur leur position chronologique et leur attribution culturelle". Paleo 14: 201-4.

HUBLIN, J.-J.; BARROSO RUIZ, C.; MEDINA LARA, P.; FONTUGNE, M. and REYSS, J.L. 1995: "The Mousterian Site of Zafarraya (Andalucia, Spain): Dating and Implications on the Paleolithic Peopling Processes of Western Europe". Comptes-Rendus de l'Académie des Sciences de Paris 321 (2 a): 931-7.

HUBLIN, J. J.; SPOOR, F.; BRAUN, F.; ZONNEVELD, F. and CONDEMI, S. 1996: "A Late Neanderthal Associated with Upper Palaeolithic Artefacts". Nature 381: 224-6.

JÖRIS, O. 2003: “Zur chronostratigraphischen Stellung der spätmittelpaläolitischen Keilmessergruppen. Der Versucht einer kulturgeographischen Abgrenzung einer mittelpaläolitischen Formengruppe und ihr europäischer Kontext”. Ber. Röm.-German. Komm. 84 (e.p.).

JÖRIS, O.; ÁLVAREZ FERNÁNDEZ, E. and WENINGER, B. 2001: "Radiocarbon Evidence of the Middle to Upper Palaeolithic Transition on the Iberian Peninsula". XIVe Congrès de l'UISPP, 2-8 September (Pre-Prints), Liège: 141.

JÖRIS, O. and WENINGER, B. 1998: "Extension of the ${ }^{14} \mathrm{C}$ Calibration Curve to ca. 40,000 calBC by Synchronizing Greenland ${ }^{18} \mathrm{O} /{ }^{16} \mathrm{O}$ Ice Core Records and North Atlantic Foraminifera Profiles: a Comparison with U/Th Coral Data". Radiocarbon 40: 495-504.

- 1999 a: "Possibilities of Calendric Conversion of Radiocarbon Data for the Glacial Periods". In J. Evin, C. Oberlin, J. P. Daugas and J. F. Salles (eds.): Actes du 3ème Congr. Int. "Archéologie et 14C". Rev. d'Archéometrie Suppl. 1999 et Soc. Préhist. Franç. Mémoire 26. Lyon: 87-92.

- 1999 b: "Calendric Age-Conversion of Glacial Radiocarbon Data at the Transition from the Middle to Upper Palaeolithic in Europe". Bull. Soc. Préhist. Luxembourgeoise 18: 43-55.

- 2000: "Approaching the Calendric Age Dimension at the Transition from the Middle to Upper Palaeolithic in Europe". In J. Orschied and G.-Chr. Weniger (eds.): Neanderthals and Modern Humans - Discussing the Transition: Central and Eastern Europe from 50.000-
30.000 BP. Wissenschaftliche Schriften des Neanderthal Museums 2. Mettmann: 13-9.

KITAGAWA, H. and VANDER PLICHT, J. 2000: "Atmospheric Radiocarbon Beyond 11.900 calBP from Lake Suigetsu Laminated Sediments". Radiocarbon 42:36980.

KRINGS, M.; GEISERT, H.; SCHMITH, R.; KRAINITZKI, H. and PÄÄBO, Sv. 1999: "DNA Sequence of the Mitochondrial Hypervariable Region II from the Neanderthal Type Specimen". Proc. Nat. Acad. Sci. U.S.A. 96: 5581-5.

KRINGS, M.; STONE, A.; SCHMITZ, R. W.; KRAINITZKI, H.; STONEKING, M. and PÄÄBO, Sv. 1997: "Neandertal DNA Sequences and the Origin of Modern Humans". Cell 90: 19-30.

LANTING, J. N. and A. L. BRINDLEY 1999: "Fechando hueso cremado: la base científica”. Trabajos de Prehistoria 56 (2): 137-40.

MAÍLLO FERNÁNDEZ, J. M. 2003: La transición Paleolítico Medio-Superior en Cantabria: análisis tecnológico de la industria lítica de Cueva Morín. Doctoral thesis UNED, Madrid.

MONTES BARQUÍN, R. 2000: “Actuaciones arqueológicas en la cueva de El Pendo (Escobedo de Camargo)". En R. Ontañón Peredo (Coor.): Actuaciones Arqueológicas en Cantabria, 1984-1999. Gobierno de Cantabria, Consejería de Cultura. Santander: 253-8.

MONTES BARQUÍN, R. and SANGUINO GONZÁLEZ, J. 2001: La Cueva de El Pendo. Actuaciones Arqueológicas 1994-2000. Consejería de Cultura, Turismo y Deporte del Gobierno de Cantabria. Santander.

MOOK, W. G. 1983: " ${ }^{14} C$ Calibration Curves Depending on Sample Time Width". Proc. Symp. ${ }^{14}$ C and Archaeology 8: 571-625.

OVCHINNIKOV, I. V.; GÖTHERSTRÖM, A.; ROMANOVA, G. P.; KHARITONOV, V. M.; LIDÉN, K. and GOODWIN, W. 2000: "Molecular Analysis of Neanderthal DNA from the Northern Caucasus". Nature 404: 490-3.

PALMA DI CESNOLA, A. 1993: Il Paleolithico superiore in Italia. Firenze 1993.

PETTITT, P. 1999: "Neanderthal Extinction: Radiocarbon Chronology, Problems, Prospects and an Interpretation of the Existing Data". In J. Evin, J. C. Oberlin, J. P. Daugas and J. F. Salles (eds.): Actes du 3ème Congr. Int. Archéologie et 14C'. Rev. d'Archéometrie Suppl. 1999 et Soc. Préhist. Franc. Mémoire 26. Lyon: 165-70.

PETTITT, P. B. and PIKE, A. W. G. 2001: "Blind in a Cloud of Data. Problems with the Chronology of Neanderthal Extinction and Anatomically Modern Human Expansion". Antiquity 75: 415-20.

van der PLICHT, J. 2002: "Calibration of the ${ }^{14} \mathrm{C}$ Time Scale: Towards the Complete Dating Range". Netherlands Journal of Geosciences / Geologie en Mijnbouw 81: 85-96.

RIEK, G. 1932: "Paläolitische Station mit Tierplastiken und 
menschlichen Skelettresten bei Stetten ob Lontal". Germania 16: 1-8.

- 1934: Die Eiszeitjägerstation am Vogelherd im Lonetal, I: Die Kulturen. Akademische Buchhandlung Franz F. Heine. Tübingen.

RIGAUD, J. Ph. 2001: “A propos de la contemporanéité du Castelperronien et de l'Aurignacian ancien dans le nordest de l'Aquitaine: une révision des données et ses implications". In J. Zilhão, Th. Aubry and A. F. Carvalho (eds.): Les premieres hommes modernes de la Péninsule Ibérique. Actes du Colloque de la Commission VIII de l'UISPP (Vila Nova de Foz Cõa, 22-24 Octobre 1998). Instituto Portugês de Arqueología. Lisboa: 61-8.

RINK, J.; SCHWARCZ, H.P.; LEE, H.K.; CABRERA VALDÉS, V.; BERNALDO DE QUIRÓS, F. and HOYOS, M. 1996: "ESR Dating of Tooth Enamel: Comparision with AMS C-14 at El Castillo Cave, Spain". Journal of Archaeological Science 23: 945-51.

ROSELL ARDÈVOL, J.; HUGUET PÁMIES, R.; AÈMENE, M.; ANGELUCCI, D. E.; CANALS SOLOMÓ, A.; PASTÓ MARÍN, I. and RODRÍGUEZ ÁLVAREZ, J. P. 2000: "El yacimiento de las Fuentes de San Cristóbal (Veracruz, Huesca): un nuevo enclave del Paleolítico medio en el Prepirineo". En N. Bicho, E. Carbonell i Roura, B. Hockett, A. Moure Romanillo, L. Raposo, M. Santonja Gómez and G. Vega Toscano (Coor.): Actas del $3^{\circ}$ Congresso de Arqueologia Peninsular (Vila Real, 21-27 de Setembro de 1999) Vol. 2: Paleolítico da Península Ibérica. ADECAP-UTAD. Porto: 235-49.

SCHWARCZ, H. P. 2001: "Dating Bones and Teeth: The Beautiful and the Dangerous". In Ph. V. Tobias, M. A. Raath, J. Moggi-Cecchi and G. A. Doyle (eds.): Humanity from African Naissance to Coming Millennia. Colloquia in Human Biology and Palaeonthropoly. Firenze University Press. Fireze: 249-56.

SINITSYN, A. A.; HAESAERTS, P., DAMBLON, F.; VAN DER PLICH, J. and FORMAN, S. L. 2002: “New Absolute Dates in Radiocarbon Sequences of Kostenki 14 (Markina Gora)". Oso'ennosti Raebitija Berchiego Paleolita Vostoèioj Evropy. Kostenki v kontekste paleolita Evrazii. Trudy kostenkovskoj ekspedicii. Institut Istorii Material’noj Kultury RAS, Serija: Issledovanija 1. Sankt Petersburg: 250-5.

SONNEVILLE-BORDES, D. 1972: "Environnement et culture de l'homme du Périgordien ancien dans le sudouest de la France: données récentes". In F. Bordes (ed.): The Origin of Homo Sapiens. Proceedings of the Paris Symposium, 2-5 September 1969. UNESCO. Paris: 141-6.

STRINGER, Chr. 2003: "Human evolution: Out of Ethiopia”. Science 423: 692-5.

STRINGER, C. B. and ANDREWS, P. 1988: "Genetic and Fossil Evidence for the Origin of Modern Humans". Science 239: 1263-8.

STUIVER, M. and GROOTES, P. M. 2000: "GISP2 Oxygen Isotope Ratios”. Quaternary Research 53 : 277-84.
TAVOSO, A. 1976: "La Grotte Tournal ou Grande Grotte de Bize". In H. de Lumley (dir.): Provence et Languedoc Méditerranéen sites Paléolithiques et Néolithiques. Livret-Guide de 1'Excursion C2, IX Congrès UISPP (Nice, 13-18 Septembre 1976). Nice: 232-9.

VEGA TOSCANO, L. G. 1990: "La fin du Paléolithique moyen au Sud de 1'Espagne. Ses implications dans le contexte de la Péninsule Ibérique”. In C. Farizy (ed.): Paléolithique moyen récent et Paléolithique supérieur ancien en Europe. 3. Mémoires du Musée de Préhistoire d'Ile de France. Nemours: 169-76.

- 1993: "El tránsito del Paleolítico Medio al Paleolítico Superior en el sur de la Península Ibérica”. In V. Cabrera Valdés (ed.): El origen del Hombre Moderno en el suroeste de Europa. UNED. Madrid: 147-70.

VOELKER, A.; SARNTHEIN, M.; GROOTES, P. M.; ERLENKEUSER, H.; LAJ, C.; MAZAUD, A.; NADEAU, M. J. and SCHLEICHER, M. 1998: “ Correlation of Marine ${ }^{14} \mathrm{C}$-ages from the Nordic Seas with the GISP2 Isotopic Record: Implications for Radiocarbon Calibration Beyond 25 ka BP “. Radiocarbon 40: 517 34.

VOELKER, A. H. L.; GROOTES, P. M.; NADEAU, M. J. and SARNTHEIN, M. 2000: " ${ }^{14} \mathrm{C}$ Levels in the Icelandic Sea from 25-53 ka and their Link to the Earth's Magnetic Field Intensity". Radiocarbon 42: 437-52.

WHITE, T.; ASFAW, B.; DEGUSTA, D.; GILBERT, H.; RICHARDS, G. D.; SUWA, G. and HOWELL, F. C. 2003: "Pleistocene Homo sapiens from Middle Awash, Ethiopia”. Science 423: 742-7.

ZILHÃO, J. 1993: "Le passage du Paléolithique Moyen au Paléolithique Supérieur dans le Portugal". In V. Cabrera Valdés (ed.): El origen del Hombre Moderno en el suroeste de Europa. UNED. Madrid: 127-45.

- 1997: O Paleolítico Superior da Estremadura Portuguesa. Edicioes Colibri. Facultade de Letras de Lisboa. Lisboa. I

- 2000 a: "Nature and Culture in Portugal from 30.000 to 20.000 BP". In W. Roebroeks, M. Mussi, Svoboda, J. and K. Fennema (eds.): Hunters of the Golden Age. The Mid-Upper Palaeolithic of Eurasia 30.000-20.000 BP. University of Leiden. Leiden: 337-54.

- 2000 b: "The Ebro Frontier: A Model for the Late Extinction of Iberian Neanderthals". In C. B. Stringer, R. N. E. Barton and J. C. Finlayson (eds.): Neanderthals on the Edge. Papers from a Conference Marking the $150^{\text {th }}$ Anniversary of the Forbes' Quarry Discovery, Gribraltar. Oxbow Books. Oxford: 111-21.

ZILHÃO, J. and d'ERRICO, F. 1999: "The Chronology and Taphonomy of the Earliest Aurignacian and Its Implications for the Understanding of Neandethal Extinction". Jounal of World Prehistory 13: 1-68.

ZUBROW, E. 1989: "The Demographic Modelling of Neanderthal Extinction". In P. Mellars and C. Stringer (eds.): The Human Revolution. Princenton University Press. New Jersey: 121-31. 